Bull. Chem. Soc. Ethiop. 2019, 33(3), 451-466.

ISSN 1011-3924

(c) 2019 Chemical Society of Ethiopia and The Authors

Printed in Ethiopia

DOI: https://dx.doi.org/10.4314/bcse.v33i3.6

\title{
SPECTRAL CHARACTERIZATION AND ANTIMICROBIAL ACTIVITY OF SOME TRANSITION METAL COMPLEXES OF 2-(5-NITRO-1H-BENZIMIDAZOL-2-YL)-4- BROMOPHENOL
}

\author{
Aydin Tavman $^{1 *}$, Mayram Hacioglu ${ }^{2}$, Demet Gürbüz ${ }^{1}$, Adem Cinarli ${ }^{1}$, M.A. Faruk Oksüzömer ${ }^{3}$, \\ A. Seher Birteksöz Tan ${ }^{2}$ \\ ${ }^{1}$ Istanbul University - Cerrahpasa, Faculty of Engineering, Department of Chemistry, 34320, \\ Avcilar, Istanbul, Turkey \\ ${ }^{2}$ Istanbul University, Faculty of Pharmacy, Department of Pharmaceutical Microbiology, 34452, \\ Beyazit, Istanbul, Turkey \\ ${ }^{3}$ Istanbul University - Cerrahpasa, Faculty of Engineering, Department of Chemical \\ Engineering, 34320, Avcilar, Istanbul, Turkey
}

(Received May 17, 2018; Revised October 11, 2019; Accepted October 21, 2019)

\begin{abstract}
MnCl}_{2}, \mathrm{FeCl}_{3}, \mathrm{Ru}(\mathrm{DMSO})_{4} \mathrm{Cl}_{2}, \mathrm{CoCl}_{2}, \mathrm{NiCl}_{2}, \mathrm{PdCl}_{2}, \mathrm{CuCl}_{2}, \mathrm{AgNO}_{3}, \mathrm{CdCl}_{2}$ and $\mathrm{HgCl}_{2}$ complexes of 2-(5-nitro-1H-benzimidazol-2-yl)-4-bromophenol $(\mathbf{H L})$ were synthesized and characterized. The structures of the complexes were confirmed on the basis of elemental analysis, TGA, molar conductivity and magnetic moment measurements, FT-IR, far-IR, FT-Raman, UV-Visible, NMR and fluorescence spectroscopy. According to the analytical and spectral data, the ligand acted as bidentate, via the imine nitrogen and the phenolate oxygen atoms towards to the metal ions except the $\operatorname{Ag}(\mathrm{I})$. The complexes were screened for in vitro antibacterial activities against $S$. aureus, $S$. epidermidis, E. coli, K. pneumoniae, $P$. aeruginosa, $P$. mirabilis and for antifungal activity against $C$. albicans. Ciprofloxacin and fluconazole were used as reference for antibacterial and antifungal activities of the complexes, respectively. In most cases, the complexes tested showed considerable activity on $S$. aureus especially, which is a Gram positive bacterium. In addition, the $\mathrm{Hg}$ (II) and $\mathrm{Ag}(\mathrm{I})$ complexes were found to have superior activity toward all of the microorganisms whereas the $\mathrm{Pd}(\mathrm{II})$ and $\mathrm{Cd}(\mathrm{II})$ complexes showed considerably antimicrobial effect on $S$. aureus and C. albicans selectively.
\end{abstract}

KEY WORDS: Benzimidazole, Bromophenol, Transition metal complexes, Antibacterial, Antifungal

\section{INTRODUCTION}

It is known that biological metal ions play key roles in the structural organization and activation of certain enzymes, which are involved in the transfer of genetic information from DNA, leading to the synthesis of specific proteins. Transition metal complexes have attracted attentions of inorganic, metallo-organic as well as bio-inorganic chemists because of their extensive applications in wide ranging areas from material to biological sciences [1].

Antimicrobial activity of some 2-(1H-benzimidazol-2-yl)-phenol derivatives and their metal complexes were investigated in detail against some microorganisms. In our previous studies, we found that various benzimidazolyl-phenol derivatives and some of their complexes showed antimicrobial activity against several microorganisms [2-6]. For instance, $2-\left(5-\mathrm{H} / \mathrm{Me} / \mathrm{Cl} / \mathrm{NO}_{2}-\right.$ $1 H$-benzimidazol-2-yl)-4-Br/ $\mathrm{NO}_{2}$-phenols were effective especially on $S$. aureus; their $\mathrm{Ag}(\mathrm{I})$ and $\mathrm{Hg}(\mathrm{II})$ complexes showed high antimicrobial activity toward six bacteria in the study [2]. The $\mathrm{Fe}(\mathrm{III})$ complexes of 2-(5-H/Me-1H-benzimidazol-2-yl)-4- $\mathrm{Br} / \mathrm{NO}_{2}$-phenols exhibited considerable activity against $S$. aureus and $S$. epidermidis [3]. 2-(5-H/Me/Cl-1H-benzimidazol2-yl)-phenols and their Fe(III) complexes showed considerable activity on some bacteria and fungi [4]. It was reported that the $\mathrm{Co}(\mathrm{II})$ and $\mathrm{Ni}(\mathrm{II})$ chelates of 2-(1H-benzimidazol-2-yl)-phenol have antifungal activity against $A$. alternata and $A$. niger $[5,6]$.

*Corresponding author. atavman@istanbul.edu.tr

This work is licensed under the Creative Commons Attribution 4.0 International License 
2-Methoxy-6-(5-H/Me/Cl/ $\mathrm{NO}_{2}-1 H$-benzimidazol-2-yl)-phenols and their some transition metal complexes were synthesized and characterized. Some ligands and $\mathrm{Cu}(\mathrm{II})$ and $\mathrm{Zn}$ (II) complexes showed antibacterial activity against Gram positive bacteria [7]. It was reported that 4-methoxy-2-(1H-benzimidazol-2-yl)-phenol and its $\mathrm{Ag}(\mathrm{I})$ and $\mathrm{Cu}(\mathrm{II})$ complexes are effective on $S$. epidermidis, $S$. aureus and B. subtilis. Also, 4-methoxy-2-(5-methyl/chloro- $1 H$ benzimidazol-2-yl)-phenols showed antibacterial activity toward S. aureus [8]. $\mathrm{Ag}(\mathrm{I})$ and $\mathrm{Zn}(\mathrm{II})$ complexes of 2-methyl-6-(1H-benzimidazol-2-yl)-phenol showed antibacterial effect toward $K$. pneumoniae, $S$. epidermidis and $S$. aureus bacteria whereas the ligand itself had no any activity [9]. 2-(5-H/Me/F/Cl/ $/ \mathrm{NO}_{2}-1 H$-benzimidazol-2-yl)-benzene-1,4-diols $\left(\mathrm{HL}_{\mathrm{x}}: \mathrm{x}=1-5\right)$ and $\mathrm{HL}_{1}$ complexes with $\mathrm{Fe}\left(\mathrm{NO}_{3}\right)_{3}, \mathrm{Co}\left(\mathrm{NO}_{3}\right)_{2}, \mathrm{Ni}\left(\mathrm{NO}_{3}\right)_{2}, \mathrm{Cu}\left(\mathrm{NO}_{3}\right)_{2}, \mathrm{Zn}\left(\mathrm{NO}_{3}\right)_{2}$ showed considerable antimicrobial activity [10]. $\mathrm{Pd}(\mathrm{II}), \mathrm{Ag}(\mathrm{I})$ and $\mathrm{Au}(\mathrm{III})$ complexes of 4-(1H-benzimidazol-2-yl)benzene-1,3-diol showed considerable antibacterial and antifungal activity whereas the ligand itself has no any activity [11].

Spectral characterizations and antibacterial effect of $2-\left(5-\mathrm{H} / \mathrm{Cl} / \mathrm{Me} / \mathrm{NO}_{2}-1 H\right.$-benzimidazol-2yl)-4-Me/Br-phenols $\left(\mathrm{HL}_{1}-\mathrm{HL}_{5}\right)$ and their some transition metal complexes were reported by us: while $\mathrm{HL}_{1}$ ligand has considerable antibacterial activity on B. cereus only; it's $\mathrm{Ag}(\mathrm{I})$ complex show antibacterial effect toward almost to the all bacteria. $\mathrm{HL}_{5}$ and $\left[\mathrm{Zn}\left(\mathbf{L}_{5}\right)_{2}\right] \cdot \mathrm{HClO}_{4}$ exhibit considerable high antibacterial activity toward $K$. pneumoniae, B. cereus, S. epidermidis and $B$. subtilis [12].

3-(5-H/Me/Cl/ $\mathrm{NO}_{2}-1 H$-benzimidazol-2-yl)-benzene-1,2-diols $\left(\mathrm{HL}_{\mathrm{X}}: \mathrm{x}=1-4\right)$ ligands and $\mathrm{HL}_{3}$ complexes with $\mathrm{Fe}\left(\mathrm{NO}_{3}\right)_{3}, \mathrm{Cu}\left(\mathrm{NO}_{3}\right)_{2}, \mathrm{Co}\left(\mathrm{NO}_{3}\right)_{2}, \mathrm{Zn}\left(\mathrm{NO}_{3}\right)_{2}$ have been synthesized and characterized. $\mathrm{HL}_{1}, \mathrm{HL}_{2}, \mathrm{HL}_{3}$ and $\left[\mathrm{Cu}\left(\mathbf{L}_{3}\right)_{2}\right] \cdot\left(\mathrm{H}_{2} \mathrm{O}\right)_{2}$ show considerable antimicrobial activity toward S. epidermidis and C. albicans [13].

Coordination compounds exhibit different characteristic properties depend on the metal ion that they are bonded [14]. These metal complexes have extensive applications in various fields of human interest on the basis of nature of the metal as well as the type of ligand $[15,16]$. Chelation or complexation shows more potent antibacterial effect against some microorganisms than the respective drug [17-19]. We reported that 2-(5-nitro- $1 H$-benzimidazol-2-yl)-4bromophenol (HL) ligand and its $\mathrm{Zn}\left(\mathrm{NO}_{3}\right)_{2}, \mathrm{Fe}\left(\mathrm{NO}_{3}\right)_{3}$ and $\mathrm{Cu}\left(\mathrm{NO}_{3}\right)_{2}$ complexes showed strong antibacterial activity toward $S$. aureus and $S$. epidermidis [20, 21]. In this study, we aimed to synthesize the new transition metal complexes of $\mathbf{H L}$ (Figure 1) with $\mathrm{MnCl}_{2}, \mathrm{FeCl}_{3}$, $\mathrm{Ru}(\mathrm{DMSO})_{4} \mathrm{Cl}_{2}, \mathrm{CoCl}_{2}, \mathrm{NiCl}_{2}, \mathrm{PdCl}_{2}, \mathrm{CuCl}_{2}, \mathrm{AgNO}_{3}, \mathrm{CdCl}_{2}$ and $\mathrm{HgCl}_{2}$ and to investigate their structural characteristics and antimicrobial activities toward six bacteria and one fungi, $C$. albicans.

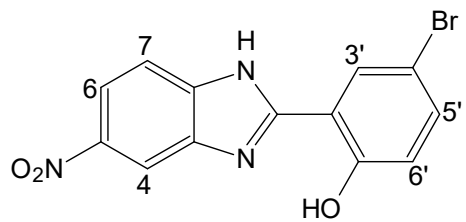

Figure 1. Structure of the ligand.

\section{EXPERIMENTAL}

Chemistry and apparatus

All chemicals and solvents were of reagent grade from Sigma-Aldrich, Merck, Alfa Easer, Carlo Erba and Acros Organics and they were used without further purification.

Analytical data were obtained with a Thermo Finnigan Flash EA 1112 analyzer. Melting points were determined using an Electrothermal melting-point apparatus. Molar conductivity of the complexes was measured on a WTW Cond $315 \mathrm{i}$ conductivity meter in DMF at $25{ }^{\circ} \mathrm{C} .{ }^{1} \mathrm{H}-$ NMR spectra were run on a Varian Unity Inova 500 NMR spectrometer. The residual DMSO- $\mathrm{d}_{6}$ 
signal was also used as an internal reference. FT mid-IR and far-IR spectra were recorded on a Bruker Optics Vertex 70 spectrometer using Attenuated Total Reflection (ATR) techniques between 100 and $4000 \mathrm{~cm}^{-1}$. The FT-Raman spectra were also recorded in the same instrument with a R100/R RAMII Raman module equipped with Nd:YAG laser source operating at 1064 $\mathrm{nm}$ line with $200 \mathrm{~mW}$ power and a spectral resolution of $\pm 2 \mathrm{~cm}^{-1}$. UV-Visible spectra was performed on a Perkin Elmer Lambda $25 \mathrm{UV} /$ Visible Spectrometer in MeOH. Fluorescence spectra were performed on a Shimadzu RF-5301 PC Spectrofluorophotometer. Thermogravimetric studies were made on a TG-60WS Shimadzu, with a heating rate of 10 ${ }^{\circ} \mathrm{C} / \mathrm{min}$ and air flowing at the rate of $50 \mathrm{~mL} / \mathrm{min}$. Magnetic measurements of the paramagnetic complexes were carried out on MK1 Sherwood Scientific apparatus at room temperature by Gouy's method. Diamagnetic corrections were made using Pascal's constants.

\section{Synthesis of the ligand}

The ligand was prepared according to the literature procedures [22, 23]. 2-Hydroxy-5bromobenzaldehyde $(2.01 \mathrm{~g}, 10 \mathrm{mmol})$ reacted with an equivalent amount of $\mathrm{NaHSO}_{3}(1.04 \mathrm{~g}$, $10 \mathrm{mmol})$ in ethanol $(25 \mathrm{~mL})$ at room temperature for $4 \mathrm{~h}$. The mixture was treated with 4-nitro1,2-phenylenediamine $(1.53 \mathrm{~g}, 10 \mathrm{mmol})$ in dimethylformamide $(15 \mathrm{~mL})$ and gently refluxed for $2 \mathrm{~h}$. The reaction mixture was then poured into iced water $(500 \mathrm{~mL})$ and then a precipitate was formed. It was filtered and crystallized from ethanol. Yield: $2.04 \mathrm{~g} \mathrm{(61 \% ).}$

\section{Synthesis of the complexes}

The metal complexes were synthesized by treating an ethanolic solution of the ligand with an equimolar amount of metal salts under reflux about $2 \mathrm{~h}$ except the $\operatorname{Ag}(\mathrm{I})$ complex.

$\left[\mathrm{Mn}(\boldsymbol{L})_{2}\left(\mathrm{H}_{2} \mathrm{O}\right)\right] \cdot \mathrm{H}_{2} \mathrm{O}$. Equimolar amount of the ligand $(167 \mathrm{mg}, 0.5 \mathrm{mmol})$ and $\mathrm{MnCl}_{2} \cdot 6 \mathrm{H}_{2} \mathrm{O}$ $(117 \mathrm{mg}, 0.5 \mathrm{mmol})$ were mixed in ethanol $(20 \mathrm{~mL})$. This mixture was refluxed for $2 \mathrm{~h}$ and then filtered. After 2 days, a brown precipitate was formed in the filtrate. It was filtered and dried at room temperature. Yield: $155 \mathrm{mg}(65 \%)$.

$\left[\mathrm{Fe}(\boldsymbol{L})_{2}(\mathrm{OH})\left(\mathrm{H}_{2} \mathrm{O}\right)\right] \cdot 2 \mathrm{H}_{2} \mathrm{O} .135 \mathrm{mg}$ of $\mathrm{FeCl}_{3} \cdot 6 \mathrm{H}_{2} \mathrm{O}(0.5 \mathrm{mmol})$ were added to the ligand (167 $\mathrm{mg}, 0.5 \mathrm{mmol})$ solution in ethanol $(20 \mathrm{~mL})$. The black mixture was refluxed for $2 \mathrm{~h}$ and then filtered. In the filtrate, a black precipitate was formed after 3-4 days staying at room temperature. It was filtered and dried at room temperature. Yield: $156 \mathrm{mg}(68 \%)$.

$\left[\mathrm{Ru}(\boldsymbol{L})_{2}(\mathrm{DMSO})_{2} \mathrm{Cl}\right] \cdot 4 \mathrm{H}_{2} \mathrm{O} .242 \mathrm{mg}$ of $\mathrm{Ru}(\mathrm{DMSO})_{4} \mathrm{Cl}_{2}(0.5 \mathrm{mmol})$ were added to the ligand $(167 \mathrm{mg}, 0.5 \mathrm{mmol})$ solution in ethanol $(20 \mathrm{~mL})$. The black mixture was refluxed for $2 \mathrm{~h}$ and then filtered. In the filtrate, a black precipitate was formed after a week staying at room temperature. It was filtered and dried at room temperature. Yield: $180 \mathrm{mg}(68 \%)$.

$\left[\mathrm{Co}(\boldsymbol{H L}) \mathrm{Cl}_{2}\left(\mathrm{H}_{2} \mathrm{O}\right)_{2}\right] \cdot 2 \mathrm{H}_{2} \mathrm{O} .119 \mathrm{mg}$ of $\mathrm{CoCl}_{2} \cdot 6 \mathrm{H}_{2} \mathrm{O}(0.5 \mathrm{mmol})$ were added to the ligand (167 $\mathrm{mg}, 0.5 \mathrm{mmol})$ solution in ethanol $(20 \mathrm{~mL})$. The mixture was refluxed for $2 \mathrm{~h}$, and a slightly turbid solution was formed. It was filtered after cooling and left at room temperature. A brown precipitate was obtained from the filtrate after 2 days. It was filtered and dried at room temperature. Yield: $185 \mathrm{mg}(69 \%)$.

[Ni( $\left.\boldsymbol{H L}) \mathrm{Cl}_{2}\left(\mathrm{H}_{2} \mathrm{O}\right)_{2}\right] \cdot 4 \mathrm{H}_{2} \mathrm{O} .120 \mathrm{mg}$ of $\mathrm{NiCl}_{2} \cdot 6 \mathrm{H}_{2} \mathrm{O}(\sim 0.5 \mathrm{mmol})$ were added to the ligand (167 $\mathrm{mg}, 0.5 \mathrm{mmol})$ solution in ethanol $(20 \mathrm{~mL})$. The mixture was refluxed for $2 \mathrm{~h}$, and a slightly turbid solution was formed as in the Co(II) complex. The brown colored precipitate formed in the filtrate after 3 days was filtered and dried at room temperature. Yield: $175 \mathrm{mg}(70 \%)$. 
$\left[\mathrm{Pd}(\boldsymbol{H L})_{2} \mathrm{Cl}_{2}\right] .88 .5 \mathrm{mg}$ of $\mathrm{PdCl}_{2}(0.5 \mathrm{mmol})$ and $74.6 \mathrm{mg}$ of $\mathrm{KCl}(1.0 \mathrm{mmol})$ were dissolved in ethanol $(5 \mathrm{~mL})$ and this solution was added to the ligand $(167 \mathrm{mg}, 0.5 \mathrm{mmol})$ solution in ethanol $(15 \mathrm{~mL})$. The mixture was refluxed for $2 \mathrm{~h}$ and filtered after cooling to room temperature. The claret red precipitate was filtered off, dried at room temperature. Yield: $195 \mathrm{mg}(75 \%)$.

$\left[\mathrm{Cu}(\boldsymbol{L})_{2}(\mathrm{EtOH})_{2}\right] \cdot \mathrm{H}_{2} \mathrm{O} .86 \mathrm{mg}$ of $\mathrm{CuCl}_{2} \cdot 2 \mathrm{H}_{2} \mathrm{O}(0.5 \mathrm{mmol})$ were added to the ligand $(167 \mathrm{mg}, 0.5$ mmol) solution in ethanol $(20 \mathrm{~mL})$. The mixture was refluxed for $2 \mathrm{~h}$ and a slightly turbid solution was obtained. The brown colored precipitate formed in the filtrate in 2 days was filtered and dried at room temperature. Yield: $160 \mathrm{mg}(74 \%)$.

$[\mathrm{Ag}(\boldsymbol{H} \boldsymbol{L})(\boldsymbol{L})] \cdot \mathrm{H}_{2} \mathrm{O} .85 \mathrm{mg}$ of $\mathrm{AgNO}_{3}(0.5 \mathrm{mmol})$ were added to the equimolar ligand solution in ethanol $(20 \mathrm{~mL})$. The mixture was stirred overnight at room temperature. A slightly turbid solution was formed and filtered. The filtrate was stayed at room temperature. After 2 days a dirty white precipitate was formed. It was filtered and dried at room temperature. Yield: $121 \mathrm{mg}$ $(64 \%)$.

$[\mathrm{Cd}(\boldsymbol{H L})(\boldsymbol{L}) \mathrm{Cl}] \cdot \mathrm{H}_{2} \mathrm{O} .101 \mathrm{mg}$ of $\mathrm{CdCl}_{2} \cdot \mathrm{H}_{2} \mathrm{O}(0.5 \mathrm{mmol})$ were added to the equimolar ligand solution in ethanol $(20 \mathrm{~mL})$. The mixture was refluxed for $2 \mathrm{~h}$, and a slightly turbid solution was formed. It was filtered after cooling. The dirty white crystals were formed in the filtrate after 3 days at room temperature. It was filtered and dried at room temperature. Yield: $165 \mathrm{mg}$ (67\%).

$\left[\mathrm{Hg}(\boldsymbol{H L}) \mathrm{Cl}_{2}\right] \cdot 2 \mathrm{H}_{2} \mathrm{O}$. This complex was prepared in a similar manner to $\left[\mathrm{Cd}(\mathbf{L})_{2}\right] \cdot \mathrm{H}_{2} \mathrm{O}$ complex. $136 \mathrm{mg}$ of $\mathrm{HgCl}_{2}(0.5 \mathrm{mmol})$ was added to the equimolar ligand solution. Yield: $275 \mathrm{mg}(63 \%)$.

The analytical and physicochemical data of the complexes are presented in Table 1 .

Determination of antimicrobial activity

Antimicrobial activity against Staphylococcus aureus ATCC 6538, Staphylococcus epidermidis ATCC 12228, Escherichia coli ATCC 8739, Klebsiella pneumoniae ATCC 4352, Pseudomonas aeruginosa ATCC 27853, Proteus mirabilis ATCC 14153 and Candida albicans ATCC 10231 were determined by the microbroth dilutions technique following the Clinical and Laboratory Standards Institute (CLSI) recommendations [24, 25]. Mueller-Hinton broth (MHB) (Difco, Detroit, MI, USA) for bacteria, RPMI-1640 medium buffered to $\mathrm{pH} 7.0$ with MOPS (Sigma, St. Louis, MO, USA) for yeast strain was used as the test medium. Serial two-fold dilutions ranging from $5000 \mu \mathrm{g} / \mathrm{mL}$ to $2.4 \mu \mathrm{g} / \mathrm{mL}$ were prepared in MHB. The inoculum was prepared using a 4-6 $\mathrm{h}$ broth culture of each bacteria and 24 culture of yeast strains adjusted to a turbidity equivalent to a $0.5 \mathrm{McF}$ arland standard, diluted in broth media to give a final concentration of $5 \times 10^{5}$ $\mathrm{cfu} / \mathrm{mL}$ for bacteria and $0.5 \times 10^{3}$ to $2.5 \times 10^{3} \mathrm{cfu} / \mathrm{mL}$ for yeast in the test tray. The trays were covered and placed in plastic bags to prevent evaporation. The trays containing MHB were incubated at $35^{\circ} \mathrm{C}$ for $18-20 \mathrm{~h}$ and the trays containing RPMI-1640 medium were incubated at $35{ }^{\circ} \mathrm{C}$ for $46-50 \mathrm{~h}$. The minimum inhibitory concentrations (MIC) were defined as the lowest concentration of compound giving complete inhibition of visible growth. As control, antimicrobial effects of dimethylsulfoxide (DMSO) were investigated against test microorganisms. Ciprofloxacin and fluconazole were used to verify the standardization of the micro-dilution test procedure as reference antimicrobials for bacteria and yeast, respectively. According to values of the controls, the results were evaluated. The MIC values of the ciprofloxacin and fluconazole are within the accuracy range in CLSI throughout the study [26]. The experiments were performed in duplicate.

\section{RESULTS AND DISCUSSION}

The analytical data and physical properties of the complexes are summarized in Table 1. 
Table 1. The analytical data and physical properties of the ligand and the complexes.

\begin{tabular}{|c|c|c|c|c|c|c|c|}
\hline \multirow{2}{*}{ Compound } & \multicolumn{3}{|c|}{$\begin{array}{l}\text { Elemental analysis: } \\
\text { found (calcd) \% }\end{array}$} & \multirow{2}{*}{$\begin{array}{c}\text { m.p. } \\
{ }^{\circ} \mathrm{C}\end{array}$} & \multirow[t]{2}{*}{$\mathrm{M}$} & \multirow[t]{2}{*}{$\Lambda$} & \multirow[t]{2}{*}{ Color } \\
\hline & $\mathrm{C}$ & $\mathrm{H}$ & $\mathrm{N}$ & & & & \\
\hline $\begin{array}{l}\mathbf{H L} \\
\mathrm{C}_{13} \mathrm{H}_{8} \mathrm{BrN}_{3} \mathrm{O}_{3} \\
\end{array}$ & $\begin{array}{c}46.41 \\
(46.73) \\
\end{array}$ & $\begin{array}{c}2.62 \\
(2.46)\end{array}$ & $\begin{array}{c}12.81 \\
(12.66)\end{array}$ & 277 & 0 & - & $\begin{array}{c}\text { Dark } \\
\text { yellow }\end{array}$ \\
\hline $\begin{array}{l}{\left[\mathrm{Mn}(\mathbf{L})_{2}\left(\mathrm{H}_{2} \mathrm{O}\right)\right] \cdot \mathrm{H}_{2} \mathrm{O}} \\
\mathrm{C}_{26} \mathrm{H}_{18} \mathrm{Br}_{2} \mathrm{~N}_{6} \mathrm{O}_{8} \mathrm{Mn} \\
\end{array}$ & $\begin{array}{c}40.74 \\
(41.24) \\
\end{array}$ & $\begin{array}{l}2.56 \\
(2.40) \\
\end{array}$ & $\begin{array}{c}10.35 \\
(11.10) \\
\end{array}$ & $\begin{array}{c}>35 \\
0\end{array}$ & 4.00 & 58 & Brown \\
\hline $\begin{array}{l}{\left[\mathrm{Fe}(\mathbf{L})_{2}(\mathrm{OH})\left(\mathrm{H}_{2} \mathrm{O}\right)\right] \cdot 2 \mathrm{H}_{2} \mathrm{O}} \\
\mathrm{C}_{26} \mathrm{H}_{21} \mathrm{Br}_{2} \mathrm{~N}_{6} \mathrm{O}_{10} \mathrm{Fe}\end{array}$ & $\begin{array}{c}39.48 \\
(39.37) \\
\end{array}$ & $\begin{array}{l}3.01 \\
(2.67) \\
\end{array}$ & $\begin{array}{c}10.14 \\
(10.60) \\
\end{array}$ & $\begin{array}{c}>35 \\
0\end{array}$ & 5.80 & 43 & Black \\
\hline $\begin{array}{l}{\left[\mathrm{Ru}(\mathbf{L})_{2}(\mathrm{DMSO})_{2} \mathrm{Cl}\right] \cdot 4 \mathrm{H}_{2} \mathrm{O}^{1}} \\
\mathrm{C}_{30} \mathrm{H}_{34} \mathrm{Br}_{2} \mathrm{ClN}_{6} \mathrm{O}_{12} \mathrm{~S}_{2} \mathrm{Ru}\end{array}$ & $\begin{array}{c}35.09 \\
(34.95) \\
\end{array}$ & $\begin{array}{c}3.13 \\
(3.32)\end{array}$ & $\begin{array}{c}7.87 \\
(8.15) \\
\end{array}$ & $\begin{array}{c}>35 \\
0\end{array}$ & 1.42 & 13 & Black \\
\hline $\begin{array}{l}{\left[\mathrm{Co}(\mathrm{HL}) \mathrm{Cl}_{2}\left(\mathrm{H}_{2} \mathrm{O}\right)_{2}\right] \cdot 2 \mathrm{H}_{2} \mathrm{O}} \\
\mathrm{C}_{13} \mathrm{H}_{16} \mathrm{BrCl}_{2} \mathrm{CoN}_{3} \mathrm{O}_{7}\end{array}$ & $\begin{array}{c}29.42 \\
(29.13) \\
\end{array}$ & $\begin{array}{c}2.71 \\
(3.01)\end{array}$ & $\begin{array}{c}7.42 \\
(7.84) \\
\end{array}$ & $\begin{array}{c}>35 \\
0\end{array}$ & 4.66 & 36 & $\begin{array}{c}\text { Dark } \\
\text { brown }\end{array}$ \\
\hline $\begin{array}{l}{\left[\mathrm{Ni}(\mathrm{HL}) \mathrm{Cl}_{2}\left(\mathrm{H}_{2} \mathrm{O}\right)_{2}\right] \cdot 4 \mathrm{H}_{2} \mathrm{O}^{2}} \\
\mathrm{C}_{13} \mathrm{H}_{20} \mathrm{BrCl}_{2} \mathrm{~N}_{3} \mathrm{O}_{9} \mathrm{Ni}\end{array}$ & $\begin{array}{c}26.12 \\
(27.31) \\
\end{array}$ & $\begin{array}{c}3.94 \\
(3.53) \\
\end{array}$ & $\begin{array}{c}6.85 \\
(7.35) \\
\end{array}$ & $\begin{array}{c}>35 \\
0\end{array}$ & 3.14 & 123 & $\begin{array}{c}\text { Dark } \\
\text { brown }\end{array}$ \\
\hline $\begin{array}{l}{\left[\mathrm{Pd}(\mathbf{H L})_{2} \mathrm{Cl}_{2}\right]} \\
\mathrm{C}_{26} \mathrm{H}_{16} \mathrm{Br}_{2} \mathrm{Cl}_{2} \mathrm{~N}_{6} \mathrm{O}_{6} \mathrm{Pd}\end{array}$ & $\begin{array}{c}37.27 \\
(36.93) \\
\end{array}$ & $\begin{array}{c}2.11 \\
(1.91) \\
\end{array}$ & $\begin{array}{c}9.67 \\
(9.94) \\
\end{array}$ & $\begin{array}{c}>35 \\
0\end{array}$ & 0 & 18 & $\begin{array}{c}\text { Claret } \\
\text { red }\end{array}$ \\
\hline $\begin{array}{l}{\left[\mathrm{Cu}(\mathbf{L})_{2}(\mathrm{EtOH})_{2}\right] \cdot \mathrm{H}_{2} \mathrm{O}} \\
\mathrm{C}_{28} \mathrm{H}_{22} \mathrm{Br}_{2} \mathrm{~N}_{6} \mathrm{O}_{8} \mathrm{Cu}\end{array}$ & $\begin{array}{c}41.99 \\
(42.36) \\
\end{array}$ & $\begin{array}{c}3.18 \\
(2.79) \\
\end{array}$ & $\begin{array}{l}10.73 \\
(10.59) \\
\end{array}$ & $\begin{array}{c}>35 \\
0\end{array}$ & 1.75 & 52 & Brown \\
\hline $\begin{array}{l}\mathrm{Ag}(\mathbf{H L})(\mathbf{L})] \cdot \mathrm{H}_{2} \mathrm{O} \\
\mathrm{C}_{26} \mathrm{H}_{17} \mathrm{Br}_{2} \mathrm{~N}_{6} \mathrm{O}_{7} \mathrm{Ag} \\
\end{array}$ & $\begin{array}{c}38.96 \\
(39.37) \\
\end{array}$ & $\begin{array}{l}2.38 \\
(2.16) \\
\end{array}$ & $\begin{array}{c}10.25 \\
(10.60) \\
\end{array}$ & 158 & 0 & 67 & $\begin{array}{l}\text { Dirty } \\
\text { white }\end{array}$ \\
\hline $\begin{array}{l}{[\mathrm{Cd}(\mathbf{H L})(\mathbf{L}) \mathrm{Cl}] \cdot \mathrm{H}_{2} \mathrm{O}} \\
\mathrm{C}_{26} \mathrm{H}_{17} \mathrm{Br}_{2} \mathrm{ClN}_{6} \mathrm{O}_{7} \mathrm{Cd}\end{array}$ & $\begin{array}{c}38.41 \\
(37.48) \\
\end{array}$ & $\begin{array}{c}2.26 \\
(2.06)\end{array}$ & $\begin{array}{c}10.22 \\
(10.09)\end{array}$ & 292 & 0 & 10 & $\begin{array}{l}\text { Dirty } \\
\text { white }\end{array}$ \\
\hline $\begin{array}{l}{\left[\mathrm{Hg}(\mathbf{H L}) \mathrm{Cl}_{2}\right] \cdot 2 \mathrm{H}_{2} \mathrm{O}} \\
\mathrm{C}_{13} \mathrm{H}_{12} \mathrm{BrCl}_{2} \mathrm{~N}_{3} \mathrm{O}_{5} \mathrm{Hg}\end{array}$ & $\begin{array}{c}23.92 \\
(24.33) \\
\end{array}$ & $\begin{array}{c}1.73 \\
(1.89)\end{array}$ & $\begin{array}{c}6.27 \\
(6.55) \\
\end{array}$ & 221 & 0 & 31 & $\begin{array}{l}\text { Dirty } \\
\text { white }\end{array}$ \\
\hline
\end{tabular}

$\mathrm{M}$, magnetic moment, BM; $\Lambda$, molar conductivity, $\Omega^{-1} \mathrm{~cm}^{2} \mathrm{~mol}^{-1}\left(25 \pm 1^{\circ} \mathrm{C}\right)$ in DMF. ${ }^{1} \mathrm{~S} \%: 6.09$ (6.22). ${ }^{2} \mathrm{Ni} \%: 7.89$ (7.35).

\section{General properties}

HL is a bidentate, monodeprotonable and chelating ligand. Spectral characterization of $\mathbf{H L}$ and its $\mathrm{Fe}\left(\mathrm{NO}_{3}\right)_{3}, \mathrm{Cu}\left(\mathrm{NO}_{3}\right)_{2}$ and $\mathrm{Zn}\left(\mathrm{NO}_{3}\right)_{2}$ complexes were reported in previous studies $[12,13]$. In this study, $\mathrm{MnCl}_{2}, \mathrm{FeCl}_{3}, \mathrm{Ru}(\mathrm{DMSO})_{4} \mathrm{Cl}_{2}, \mathrm{CoCl}_{2}, \mathrm{NiCl}_{2}, \mathrm{PdCl}_{2}, \mathrm{CuCl}_{2}, \mathrm{AgNO}_{3}, \mathrm{CdCl}_{2}$ and $\mathrm{HgCl}_{2}$ complexes of the ligand (HL) were synthesized and characterized. $\mathrm{Mn}$ (II) $\mathrm{Fe}(\mathrm{III})$, $\mathrm{Ru}(\mathrm{III}), \mathrm{Pd}(\mathrm{II}), \mathrm{Cu}(\mathrm{II}), \mathrm{Ag}(\mathrm{I})$ and $\mathrm{Cd}(\mathrm{II})$ complexes have 1:1 M:L ratio whereas the Co(II), $\mathrm{Ni}(\mathrm{II})$ and $\mathrm{Hg}$ (II) complexes are 1:2 (bis-type).

According to the analytical data, the ligand is monodeprotonated through the phenolic $\mathrm{OH}$ hydrogen atom in most of the complexes. Molar conductivity data shows that the $\mathrm{MnCl}_{2}, \mathrm{FeCl}_{3}$, $\mathrm{Ru}(\mathrm{DMSO})_{4} \mathrm{Cl}_{2}, \mathrm{CoCl}_{2}, \mathrm{CuCl}_{2}, \mathrm{CdCl}_{2}$ and $\mathrm{HgCl}_{2}$ complexes are non-ionic (molar conductivities are in the 10-58 $\Omega^{-1} \mathrm{~cm}^{2} \mathrm{~mol}^{-1}$ range). The $\mathrm{Ag}(\mathrm{I})$ complex is a $1: 1$ ionic complex (67 $\left.\Omega^{-1} \mathrm{~cm}^{2} \mathrm{~mol}^{-1}\right)$ while the $\mathrm{Ni}(\mathrm{II})$ complex has $1: 2$ ionic character $\left(123 \Omega^{-1} \mathrm{~cm}^{2} \mathrm{~mol}^{-1}\right)$ [27].

The room temperature effective magnetic moment value of the Fe(III) complex, 5.80 BM, can be considered as indicating stabilization of the species having high ferric spin $(\mathrm{s}=5 / 2)$ state. The magnetic moment value of the $\mathrm{Cu}$ (II) complex $(1.75 \mathrm{BM})$ are very closer to the expected value $(1.73 \mathrm{BM})$ for a simple mononuclear $\mathrm{Cu}$ (II) complex. The magnetic moment value of $\mathrm{Mn}(\mathrm{II})$ complex, $4.00 \mathrm{BM}$, may be accepted indicating stabilization of the species having intermediate spin $(\mathrm{s}=3 / 2)$ state for $\mathrm{d}^{5}$ ion and can be taken into account as an indication for a five-coordinated structure and square pyramidal geometry due to theoretical magnetic moment value of three unpaired electrons is $3.88 \mathrm{BM}\left(\mathrm{d}^{5}\right.$ ion in square pyramidal environment: $\mathrm{d}_{\mathrm{xz}}{ }^{2} \mathrm{~d}_{\mathrm{yz}}{ }^{1}$ $\left.\mathrm{d}_{\mathrm{xy}}{ }^{1} \mathrm{~d}_{\mathrm{z2}}{ }^{1}\right)[28,29]$.

The magnetic moment value of $\mathrm{Co}(\mathrm{II})$ complex, 4.66 $\mathrm{BM}$, is in the expected range for octahedral complexes having high-spin state [30]. The magnetic moment value of the Ni(II) 
complex (3.14 $\mathrm{BM})$ can be considered as evidence showing a distorted octahedral geometry for $\left[\mathrm{Ni}(\mathbf{H L}) \mathrm{Cl}_{2}\left(\mathrm{H}_{2} \mathrm{O}\right)_{2}\right] \cdot 4 \mathrm{H}_{2} \mathrm{O}[31,32]$.

Surprisingly, the ruthenium complex shows paramagnetic characteristic with a magnetic moment value $1.42 \mathrm{BM}$, although $\mathrm{Ru}(\mathrm{II})$, is a $\mathrm{d}^{6}$ system, was used for complex preparation. This can be interpreted that ruthenium undergoes a one-electron oxidation during the course of the complexation reaction and in view of the ruthenium(III)/ruthenium(II) reduction potential displayed by this complex, aerial oxygen appears to have served as the oxidant. It can be interpreted that the magnetic moment value of $\mathrm{Ru}(\mathrm{III})$ complex corresponds to one unpaired electron for $\mathrm{d}^{5}$ electronic configuration despite it is lower than the expected value (1.71 $\left.\mathrm{BM}\right)$ [33]. It can be proposed capped octahedron or pentagonal bipyramid geometry for $\mathrm{Ru}(\mathrm{III})$ complex.

\section{Thermal analysis}

The major features of the thermal analysis of the complexes are summarized in Table 2. TGA curves of the $\mathrm{Mn}(\mathrm{II}), \mathrm{Ru}(\mathrm{III}), \mathrm{Co}(\mathrm{II}), \mathrm{Ni}(\mathrm{II})$ and $\mathrm{Cd}(\mathrm{II})$ complexes are shown in Figure 2. The samples of the complexes were heated from room temperature up to $800{ }^{\circ} \mathrm{C}$. Thermal analysis results exhibited the valuable information about the water coordination state of the complexes. Thermal degradation of complexes occurred in three stages. At the first stage, uncoordinated lattice water was lost through evaporation from 50 to $100{ }^{\circ} \mathrm{C}$ (Table 2 , first column). At the second stage, the coordinated water molecules are removed from all the complexes except $\mathrm{Pd}(\mathrm{II})$ complex at temperatures between 100 and $150{ }^{\circ} \mathrm{C}$ (Table 2, second column) [34, 35]. In all complexes, weight losses observed above $250^{\circ} \mathrm{C}$ can be explained in terms of cleavage of the $\mathrm{Br}$ and nitro groups and also as decomposition of the anions. Above $350{ }^{\circ} \mathrm{C}$, all other organic parts of complexes are oxidized to carbon dioxide, nitrogen oxides and water (third stage). The decomposition reactions result in the formation of metal oxides.

Table 2. TGA data of the complexes (thermal decomposition).

\begin{tabular}{|c|c|c|c|c|c|c|c|c|c|c|c|c|c|}
\hline Temperature $\left({ }^{\circ} \mathrm{C}\right) \rightarrow$ & 100 & 150 & 200 & 250 & 300 & 350 & 400 & 450 & 500 & 550 & 600 & 650 & 700 \\
\hline Complex & \multicolumn{13}{|c|}{ Weight loss (\%) } \\
\hline$\left[\mathrm{Mn}(\mathbf{L})_{2}\left(\mathrm{H}_{2} \mathrm{O}\right)\right] \cdot \mathrm{H}_{2} \mathrm{O}$ & 3.2 & 4.8 & 5.9 & 9.0 & 12.0 & 21.2 & 25.4 & 48.0 & 58.7 & 67.1 & 80.4 & 90.6 & 91.8 \\
\hline $\mathrm{Fe}(\mathrm{III})$ complex $^{\mathrm{a}}$ & 4.2 & 4.5 & 7.6 & 8.1 & 8.8 & 9.7 & 74.6 & 88.5 & 90.4 & 90.4 & 90.4 & 90.4 & 90.4 \\
\hline Ru(III) complex ${ }^{b}$ & 6.5 & 7.6 & 8.9 & 9.3 & 16.1 & 22.4 & 31.3 & 64.7 & 81.0 & 82.4 & 83.4 & 84.5 & 84.5 \\
\hline $\mathrm{Co}(\mathrm{II})$ complex $^{\mathrm{c}}$ & 6.5 & 9.5 & 11.1 & 14.5 & 17.2 & 20.6 & 26.6 & 56.6 & 64.0 & 73.5 & 84.3 & 84.9 & 84.9 \\
\hline $\mathrm{Ni}(\mathrm{II})$ complex $^{\mathrm{d}}$ & 4.9 & 7.1 & 13.2 & 16.6 & 20.3 & 25.0 & 27.0 & 37.1 & 47.2 & 63.4 & 67.8 & 79.3 & 83.3 \\
\hline$\left[\mathrm{Pd}(\mathbf{H L})_{2} \mathrm{Cl}_{2}\right]$ & 1.1 & 3.6 & 10.0 & 16.4 & 20.8 & 24.0 & 35.4 & 45.6 & 50.0 & 58.9 & 69.0 & 76.1 & 84.5 \\
\hline$\left[\mathrm{Cu}(\mathbf{L})_{2}(\mathrm{EtOH})_{2}\right] \cdot \mathrm{H}_{2} \mathrm{O}$ & 2.9 & 8.5 & 9.6 & 10.9 & 14.6 & 15.3 & 57.2 & 80.7 & 82.1 & 86.1 & 89.1 & 91.2 & 91.2 \\
\hline$[\mathrm{Ag}(\mathbf{H L})(\mathbf{L})] \cdot \mathrm{H}_{2} \mathrm{O}^{\mathrm{e}}$ & 2.2 & 2.9 & 4.5 & 9.9 & 16.0 & 19.4 & 22.1 & 26.5 & 31.5 & 37.9 & 44.0 & 53.4 & 61.5 \\
\hline$[\mathrm{Cd}(\mathbf{H L})(\mathbf{L}) \mathrm{Cl}] \cdot \mathrm{H}_{2} \mathrm{O}^{\mathrm{f}}$ & 1.9 & 2.7 & 3.6 & 5.75 & 9.3 & 11.9 & 15.0 & 19.4 & 27.3 & 33.2 & 45.7 & 69.9 & 93.7 \\
\hline$\left[\mathrm{Hg}(\mathbf{H L}) \mathrm{Cl}_{2}\right] \cdot 2 \mathrm{H}_{2} \mathrm{O}$ & 5.3 & 7.1 & 12.7 & 35.8 & 38.8 & 44.8 & 48.2 & 52.7 & 56.8 & 65.3 & 74.3 & 88.9 & 100 \\
\hline
\end{tabular}

${ }^{\mathrm{a}}\left[\mathrm{Fe}(\mathbf{L})_{2}(\mathrm{OH})\left(\mathrm{H}_{2} \mathrm{O}\right)\right] \cdot 2 \mathrm{H}_{2} \mathrm{O} ;{ }^{\mathrm{b}}\left[\mathrm{Ru}(\mathbf{L})_{2}(\mathrm{DMSO})_{2} \mathrm{Cl}\right] \cdot 4 \mathrm{H}_{2} \mathrm{O} ;{ }^{\mathrm{c}}\left[\mathrm{Co}(\mathbf{H L}) \mathrm{Cl}_{2}\left(\mathrm{H}_{2} \mathrm{O}\right)_{2}\right] \cdot 2 \mathrm{H}_{2} \mathrm{O} ;{ }^{\mathrm{d}}\left[\mathrm{Ni}(\mathbf{H L}) \mathrm{Cl}_{2}\left(\mathrm{H}_{2} \mathrm{O}\right)_{2}\right] \cdot 4 \mathrm{H}_{2} \mathrm{O} ;{ }^{\mathrm{e}}$ : $750{ }^{\circ} \mathrm{C}: 64.5 ; 800{ }^{\circ} \mathrm{C}: 69.3 ; 850{ }^{\circ} \mathrm{C}: 84.5 ;$; : $750{ }^{\circ} \mathrm{C}: 98.5 ; 800{ }^{\circ} \mathrm{C}: 100$.

TGA data are compatible with the suggested structures of the complexes. Molecular weight ratio of the amount of metal oxide show very good agreement for the proposed structures according to the TGA data. The weight loss is $100 \%$ in the $\mathrm{Hg}(\mathrm{II})$ and $\mathrm{Cd}(\mathrm{II})$ complexes around 700 and $800{ }^{\circ} \mathrm{C}$, respectively (Figure 3). This anomaly is due to the volatility in the second phase of decomposition [36, 37] $\left(\mathrm{HgO}\right.$ and $\mathrm{CdO}$ decompose around $500{ }^{\circ} \mathrm{C}$ and metallic mercury vapors at $357^{\circ} \mathrm{C}$, and metallic $\mathrm{Cd}$ vapors at $767^{\circ} \mathrm{C}$ ).

Vibrational spectroscopy

The FT-IR (mid-IR and far-IR) and FT-Raman spectral data of the compounds are given in Table 3. In addition, far-IR spectra of the $\mathbf{H L}, \mathrm{Ru}(\mathrm{III})$ and $\mathrm{Cu}(\mathrm{II})$ complexes in Figure 3 and FTRaman spectra of HL and Cd(II) complex are given in Figure 4. 
Interpretation of the Raman, mid-IR and far-IR spectra is based on changes in the spectra of the complexes relative to that of free ligand. The characteristic $v(\mathrm{O}-\mathrm{H})$ and $v(\mathrm{~N}-\mathrm{H})$ vibration frequencies of the ligand exhibit only a medium broad band at $3327 \mathrm{~cm}^{-1}$ in the IR spectra, caused by double intramolecular hydrogen bonding between the phenoxyl hydrogen atom and one of the imine nitrogen atom $[4,22,38,39]$. This band is changed significantly upon metal complexation indicating deprotonation and subsequent involvement of the phenoxyl group in metal coordination in the $\mathrm{Mn}(\mathrm{II}), \mathrm{Fe}(\mathrm{III}), \mathrm{Ru}(\mathrm{III}), \mathrm{Cu}(\mathrm{II})$ and $\mathrm{Cd}(\mathrm{II})$ complexes [40]. The phenolic oxygen atom coordination could also be supported by the appearance of medium bands at a lower frequency region ca. $535 \mathrm{~cm}^{-1}$, assignable to $v(\mathrm{M}-\mathrm{OC})$ vibration frequencies. The medium broad bands between 3300 and $3400 \mathrm{~cm}^{-1}$ in the complexes strongly support the presence of the coordinated and uncoordinated water molecules.

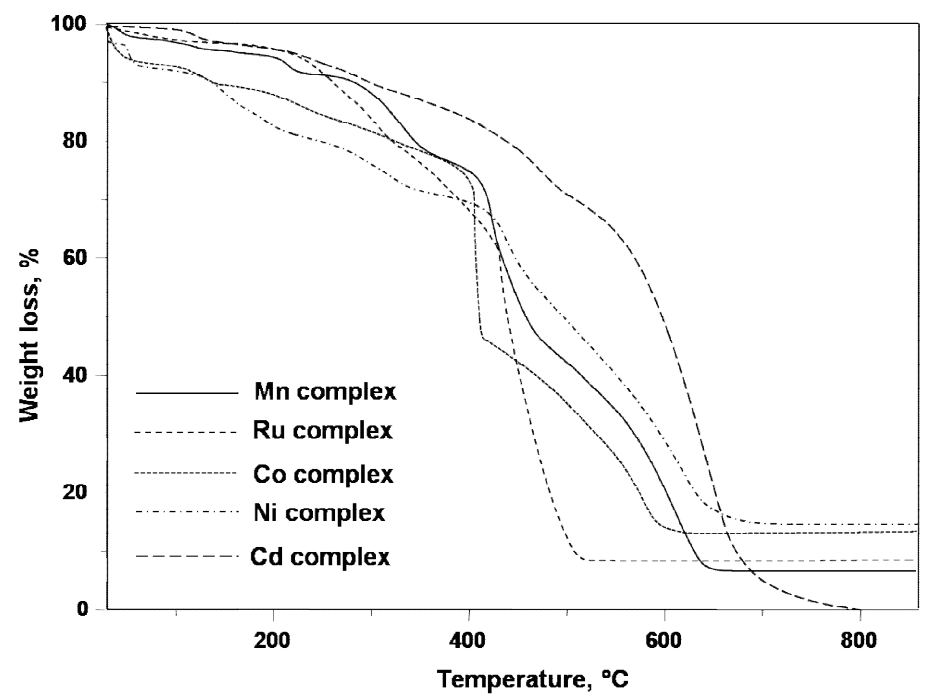

Figure 2. TGA curves of the $\mathrm{Mn}(\mathrm{II}), \mathrm{Ru}(\mathrm{III}), \mathrm{Co}(\mathrm{II}), \mathrm{Ni}(\mathrm{II})$ and $\mathrm{Cd}(\mathrm{II})$ complexes.

The characteristic $v(\mathrm{C}-\mathrm{H})$ and $\delta(\mathrm{C}-\mathrm{H})$ modes of ring residues in the ligand and the complexes are observed in the wave region between $3132-3076 \mathrm{~cm}^{-1}$ and $822-723 \mathrm{~cm}^{-1}$ (Table 3 ), respectively, particularly in the Raman spectra of the compounds. The $\mathrm{C}=\mathrm{C}$ and $\mathrm{C}=\mathrm{N}$ stretching frequencies are expected to appear at between 1631 and $1594 \mathrm{~cm}^{-1}$ with their own characteristics for the ligand and the complexes. Specific differences between spectra of the free ligand and the complexes in this region support the formation of new complexes. The coordination of imine nitrogen atom could also be confirmed by appearance of two new bands around 400 and $200 \mathrm{~cm}^{-1}$ may be assignable to $v(\mathrm{M}-\mathrm{N})$ and $\delta(\mathrm{M}-\mathrm{N})$ vibration modes $[8,41$, 42]. Similar vibrational changes are detected in the Raman spectra (Table 3 ). In the IR spectra of the ligand and the complexes, the strong or medium bands at the ranges 1514-1524 and 1308$1341 \mathrm{~cm}^{-1}$ are assigned to the symmetric and asymmetric $v\left(\mathrm{NO}_{2}\right)$, respectively. The $\mathrm{C}-\mathrm{Br}$ stretching vibration is seen at the range $525-554 \mathrm{~cm}^{-1}$ as medium bands [43].

\section{NMR spectroscopy}

${ }^{1} \mathrm{H}-\mathrm{NMR}$ spectral data of the ligand and the diamagnetic complexes and their assignments are present in Table 4. ${ }^{1} \mathrm{H}-\mathrm{NMR}$ spectra of the ligand were reported in our previous study [20]. In the HL spectra, two broad singlets are observed for the $\mathrm{NH}$ and $\mathrm{OH}$ protons at 13.41 and 12.37 
ppm, respectively. The $\mathrm{OH}$ proton appears at higher ppm values than the expected because of the hydrogen bonding between $\mathrm{C}=\mathrm{N}$ nitrogen and $\mathrm{OH}$ hydrogen atoms $[10,22]$. The $\mathrm{OH}$ and $\mathrm{NH}$ protons show considerable changes in NMR spectra on complexation. This should be connected with the coordination of the phenolic $\mathrm{OH}$ oxygen atom and removing the hydrogen bonding mentioned above.

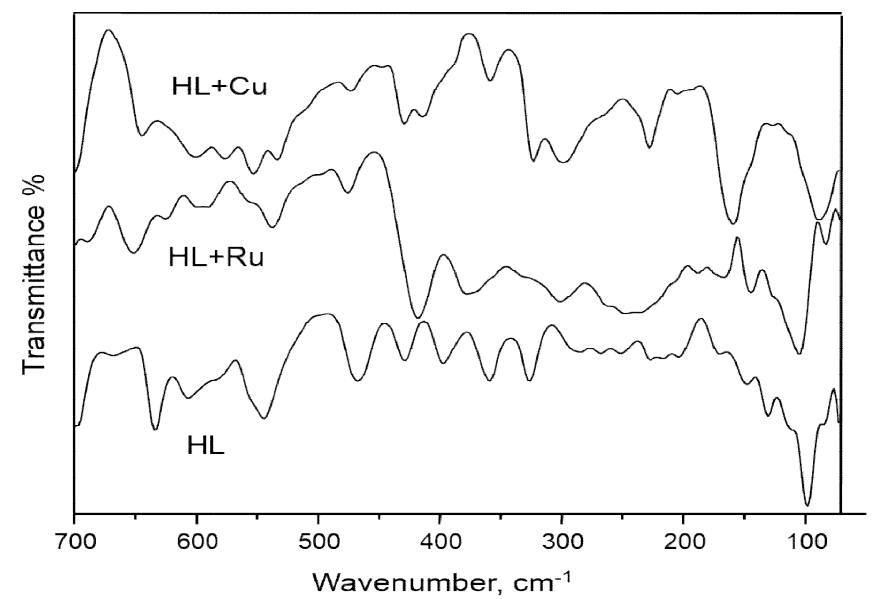

Figure 3. Far-IR spectra of the ligand and $\mathrm{Ru}(\mathrm{III})$ and $\mathrm{Cu}(\mathrm{II})$ complexes.

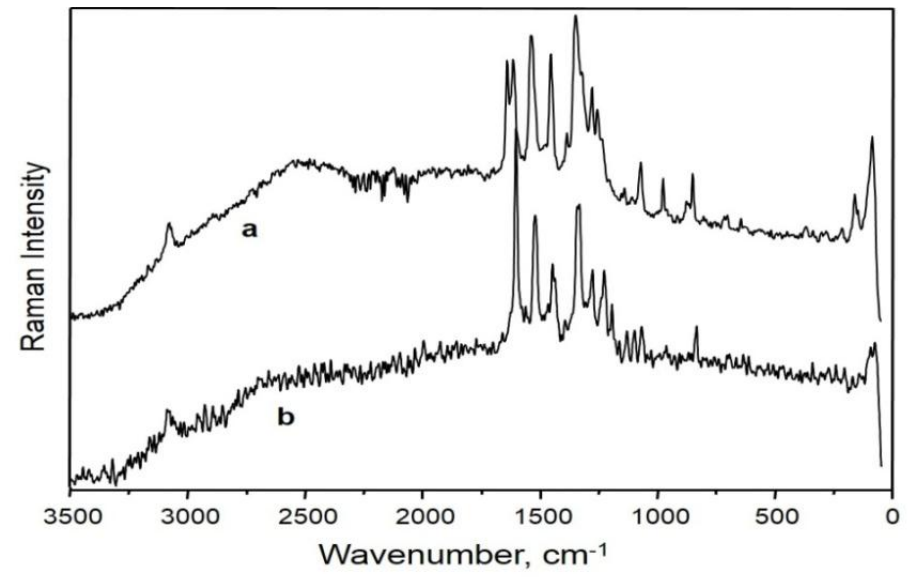

Figure 4. FT-Raman spectra of HL (a) and its Cd(II) complex (b).

Table 3. The FT-IR (mid- and far-IR) and Raman spectral data of the ligand and the complexes (frequencies, $\mathrm{cm}^{-1}$ ).

\begin{tabular}{|c|c|c|}
\hline Compound & $\begin{array}{r}\text { FT-IR } \\
\end{array}$ & \begin{tabular}{|c|} 
FT-Raman \\
\end{tabular} \\
\hline HL & $\begin{array}{l}3327 \mathrm{~m}, \mathrm{br}, 3085 \mathrm{~m}, 1630 \mathrm{~m}, 1597 \mathrm{~m}, 1583 \mathrm{~m}, \\
1518 \mathrm{~s}, 1483 \mathrm{~s}, 1339 \mathrm{~s}, 1322 \mathrm{~s}, 1249 \mathrm{~s}, 1065 \mathrm{~m}, \\
970 \mathrm{~m}, 817 \mathrm{~m}, 737 \mathrm{~m}, 633 \mathrm{~m}, 554 \mathrm{~m}, 468 \mathrm{w}, 394 \\
\mathrm{~m}, 356 \mathrm{~m}, 323 \mathrm{~m}, 224 \mathrm{w}, 144 \mathrm{w}, 127 \mathrm{w}, 96 \mathrm{~m}\end{array}$ & $\begin{array}{l}3074 \mathrm{~m}, 2978 \mathrm{w}, 2887 \mathrm{w}, 1630 \\
\mathrm{~m}, 1605 \mathrm{~m}, 1526 \mathrm{~m}, 1442 \mathrm{~m}, \\
1375 \mathrm{w}, 1337 \mathrm{~s}, 1312 \mathrm{sh}, 1269 \\
\mathrm{~m}, 1244 \mathrm{~m}, 1130 \mathrm{w}, 1060 \mathrm{~m}, \\
965 \mathrm{~m}, 867 \mathrm{w}, 840 \mathrm{~m}, 793 \mathrm{w}\end{array}$ \\
\hline
\end{tabular}

Bull. Chem. Soc. Ethiop. 2019, 33(3) 


\begin{tabular}{|c|c|c|}
\hline & & $\begin{array}{l}690 \mathrm{w}, 633 \mathrm{w}, 357 \mathrm{w}, 270 \mathrm{w}, \\
202 \mathrm{w}, 145 \mathrm{~m}, 72 \mathrm{~s}\end{array}$ \\
\hline$\left[\mathrm{Mn}(\mathbf{L})_{2}\left(\mathrm{H}_{2} \mathrm{O}\right)\right] \cdot \mathrm{H}_{2} \mathrm{O}$ & $\begin{array}{l}3346 \mathrm{~m}, 3080 \mathrm{~m}, 2907 \mathrm{w}, \mathrm{br}, 1631 \mathrm{~m}, 1603 \mathrm{~m}, \\
1522 \mathrm{~m}, 1478 \mathrm{~m}, 1438 \mathrm{~m}, 1329 \mathrm{~s}, 1256 \mathrm{~m}, 1095 \mathrm{~m}, \\
1068 \mathrm{~m}, 822 \mathrm{~m}, 737 \mathrm{~m}, 693 \mathrm{~m}, 633 \mathrm{~m}, 544 \mathrm{~m}, 460 \\
\mathrm{~m}, 382 \mathrm{w}, 354 \mathrm{~m}, 265 \mathrm{w}, 207 \mathrm{~m}, 135 \mathrm{~m}, 107 \mathrm{~m}, 87 \\
\mathrm{~m}\end{array}$ & Could not be obtained \\
\hline $\begin{array}{l}{\left[\mathrm{Fe}(\mathbf{L})_{2}(\mathrm{OH})\left(\mathrm{H}_{2} \mathrm{O}\right)\right]} \\
-2 \mathrm{H}_{2} \mathrm{O}\end{array}$ & $\begin{array}{l}\text { (A very broad band at } 3500-2500 \mathrm{~cm}^{-1} \text { range) } 3084 \\
\text { m,br, } 3067 \mathrm{~m}, \mathrm{br}, 2927 \mathrm{~m}, \mathrm{br}, 2855 \mathrm{~m}, \mathrm{br}, 1631 \mathrm{~m} \text {, } \\
1603 \mathrm{~m}, 1522 \mathrm{~m}, 1470 \mathrm{~m}, 1417 \mathrm{~m}, 1341 \mathrm{~s}, 1249 \mathrm{~m}, \\
1176 \mathrm{~m}, 878 \mathrm{~m}, 822 \mathrm{~s}, 733 \mathrm{~m}, 652 \mathrm{~m}, 624 \mathrm{~m}, 540 \\
\mathrm{~m}, 427 \mathrm{~m}, 375 \mathrm{~m}, 325 \mathrm{~m}, 281 \mathrm{~m}, 225 \mathrm{~m}, 153 \mathrm{~m}, 78 \\
\mathrm{~m}\end{array}$ & $\begin{array}{l}1592 \mathrm{~m}, 1533 \mathrm{~m}, 1478 \mathrm{~m}, 1364 \\
\mathrm{w}, 1303 \mathrm{~s}, 1245 \mathrm{~m}, 878 \mathrm{~m}, 835 \\
\text { w, } 713 \mathrm{~m}, 656 \mathrm{~s}, 478 \mathrm{w}, 421 \mathrm{~m} \\
370 \mathrm{~m}, 284 \mathrm{~m}, 190 \mathrm{w}, 129 \mathrm{~m}\end{array}$ \\
\hline $\begin{array}{l}{\left[\mathrm{Ru}(\mathbf{L})_{2}(\mathrm{DMSO})_{2} \mathrm{Cl}\right.} \\
] \cdot 4 \mathrm{H}_{2} \mathrm{O}\end{array}$ & $\begin{array}{l}3390 \mathrm{~m}, \mathrm{br}, 3092 \mathrm{~m}, \mathrm{br}, 3011 \mathrm{~m}, \mathrm{br}, 2923 \mathrm{w}, 1627 \mathrm{~m}, \\
1594 \mathrm{~m}, 1518 \mathrm{~m}, 1469 \mathrm{~m}, 1417 \mathrm{~m}, 1337 \mathrm{~s}, 1293 \mathrm{~m}, \\
1240 \mathrm{~m}, 1071 \mathrm{~m}, 1015 \mathrm{~m}, 990 \mathrm{~m}, 878 \mathrm{~m}, 822 \mathrm{~s}, \\
736 \mathrm{~m}, 692 \mathrm{~m}, 652 \mathrm{~m}, 535 \mathrm{~m}, 414 \mathrm{~m}, 375 \mathrm{~m}, 299 \\
\mathrm{~m}, 246 \mathrm{~m}, 166 \mathrm{~m}, 143 \mathrm{~m}, 106 \mathrm{~s}, 82 \mathrm{w} .\end{array}$ & Could not be obtained \\
\hline $\begin{array}{l}{\left[\mathrm{Co}(\mathbf{H L}) \mathrm{Cl}_{2}\left(\mathrm{H}_{2} \mathrm{O}\right)_{2}\right]} \\
-2 \mathrm{H}_{2} \mathrm{O}\end{array}$ & $\begin{array}{l}3382 \mathrm{~m}, \mathrm{br}, 3180 \mathrm{~m}, \mathrm{br}, 3129 \mathrm{~m}, \mathrm{br}, 2927 \mathrm{w}, \mathrm{br}, 1627 \\
\mathrm{~m}, 1599 \mathrm{~m}, 1518 \mathrm{~m}, 1474 \mathrm{~m}, 1417 \mathrm{~m}, 1337 \mathrm{~s}, 1249 \\
\mathrm{~m}, 1071 \mathrm{~m}, 982 \mathrm{~m}, 878 \mathrm{~m}, 818 \mathrm{~s}, 737 \mathrm{~m}, 692 \mathrm{~m}, \\
632 \mathrm{~m}, 544 \mathrm{~m}, 467 \mathrm{w}, 451 \mathrm{~m}, 393 \mathrm{~m}, 321 \mathrm{~m}, 276 \\
\mathrm{~m}, 208 \mathrm{~m}, 185 \mathrm{~m}, 149 \mathrm{~s}, 116 \mathrm{~m}\end{array}$ & Could not be obtained \\
\hline $\begin{array}{l}{\left[\mathrm{Ni}(\mathbf{H L}) \mathrm{Cl}_{2}\left(\mathrm{H}_{2} \mathrm{O}\right)_{2}\right] \cdot} \\
4 \mathrm{H}_{2} \mathrm{O}\end{array}$ & $\begin{array}{l}3491 \mathrm{~m}, 3382 \mathrm{~m}, 3350 \mathrm{~m}, \mathrm{br}, 3080 \mathrm{~m}, \mathrm{br}, 2923 \mathrm{~m}, \mathrm{br} \\
1627 \mathrm{sh}, 1603 \mathrm{~m}, 1519 \mathrm{~m}, 1478 \mathrm{~m}, 1337 \mathrm{~m}, 1285 \\
\mathrm{~m}, 1245 \mathrm{~m}, 1139 \mathrm{~m}, 1064 \mathrm{~m}, 882 \mathrm{~m}, 818 \mathrm{~s}, 729 \mathrm{~m}, \\
693 \mathrm{~m}, 564 \mathrm{~m}, 544 \mathrm{~m}, 471 \mathrm{~m}, 427 \mathrm{w}, 393 \mathrm{~m}, 278 \\
\mathrm{~m}, 221 \mathrm{~m}, 158 \mathrm{~m}, 116 \mathrm{~m}, 91 \mathrm{~m}\end{array}$ & $\begin{array}{l}3074 \mathrm{w}, 2811 \mathrm{w}, 1602 \mathrm{~s}, 1556 \\
\mathrm{~m}, 1520 \mathrm{~m}, 1448 \mathrm{~m}, 1330 \mathrm{~m}, \\
1290 \mathrm{~m}, 1253 \mathrm{~m}, 1063 \mathrm{~m}, 965 \\
\mathrm{w}, 839 \mathrm{~m}, 764 \mathrm{w}, 700 \mathrm{w}, 629 \\
\mathrm{w}, 75 \mathrm{~m}\end{array}$ \\
\hline$\left[\mathrm{Pd}(\mathbf{H L})_{2} \mathrm{Cl}_{2}\right]$ & $\begin{array}{l}3411 \mathrm{~m}, 3113 \mathrm{~m}, 2937 \mathrm{w}, \mathrm{br}, 1626 \mathrm{~m}, 1604 \mathrm{~m}, \\
1515 \mathrm{~m}, 1470 \mathrm{~s}, 1381 \mathrm{~m}, 1314 \mathrm{~m}, 1252 \mathrm{~m}, 1146 \mathrm{~m}, \\
1068 \mathrm{~m}, 816 \mathrm{~s}, 738 \mathrm{~m}, 693 \mathrm{~m}, 568 \mathrm{~m}, 525 \mathrm{~m}, \\
428 \mathrm{~m}, 333 \mathrm{~m}, 268 \mathrm{w}, 192 \mathrm{~m}, 159 \mathrm{~m}, 114 \mathrm{sh}, 100 \mathrm{~m}\end{array}$ & Could not be obtained \\
\hline $\begin{array}{l}{\left[\mathrm{Cu}(\mathbf{L})_{2}(\mathrm{EtOH})_{2}\right] \cdot} \\
\mathrm{H}_{2} \mathrm{O}\end{array}$ & $\begin{array}{l}3366 \mathrm{~m}, \mathrm{br}, 3328 \mathrm{~m}, \mathrm{br}, 3132 \mathrm{~m}, 1629 \mathrm{~m}, 1604 \mathrm{~m}, \\
1537 \mathrm{~m}, 1515 \mathrm{~m}, 1473 \mathrm{~m}, 1311 \mathrm{~m}, 1252 \mathrm{~m}, 1149 \\
\mathrm{~m}, 1057 \mathrm{~m}, 817 \mathrm{~s}, 736 \mathrm{~m}, 644 \mathrm{~m}, 599 \mathrm{~m}, 551 \mathrm{~m}, \\
426 \mathrm{~m}, 412 \mathrm{~m}, 357 \mathrm{~m}, 321 \mathrm{~m}, 296 \mathrm{~m}, 225 \mathrm{~m}, 156 \\
\mathrm{~m}, 87 \mathrm{~m} .\end{array}$ & Could not be obtained \\
\hline$[\mathrm{Ag}(\mathbf{H L})(\mathbf{L})] \cdot \mathrm{H}_{2} \mathrm{O}$ & $\begin{array}{l}3332 \mathrm{~m}, \mathrm{br}, 3094 \mathrm{~m}, \mathrm{br}, 2930 \mathrm{w}, \mathrm{br}, 1607 \mathrm{~m}, 1523 \mathrm{~m}, \\
1450 \mathrm{~m}, 1418 \mathrm{~m}, 1336 \mathrm{~s}, 1283 \mathrm{~s}, 1176 \mathrm{~m}, 1115 \mathrm{~m}, \\
1091 \mathrm{~m}, 877 \mathrm{~m}, 815 \mathrm{~s}, 732 \mathrm{~m}, 692 \mathrm{w}, 623 \mathrm{~m}, 573 \\
\text { w, } 541 \mathrm{~m}, 433 \mathrm{~m}, 377 \mathrm{~m}, 298 \mathrm{~m}, 239 \mathrm{~m}, 183 \mathrm{~m}, \\
159 \mathrm{~m}, 142 \mathrm{~s}, 125 \mathrm{~m}, 74 \mathrm{~m}\end{array}$ & Could not be obtained \\
\hline$[\mathrm{Cd}(\mathbf{H L})(\mathbf{L}) \mathrm{Cl}] \cdot \mathrm{H}_{2} \mathrm{O}$ & $\begin{array}{l}3350 \mathrm{~m}, 3084 \mathrm{w}, 2866 \mathrm{w}, 1626 \mathrm{~m}, 1601 \mathrm{~m}, 1524 \mathrm{~s}, \\
1477 \mathrm{~m}, 1436 \mathrm{~m}, 1331 \mathrm{~s}, 1285 \mathrm{~m}, 1258 \mathrm{~m}, 1229 \mathrm{~m}, \\
1143 \mathrm{~m}, 1093 \mathrm{~m}, 1066 \mathrm{~m}, 883 \mathrm{~m}, 818 \mathrm{~m}, 732 \mathrm{~m}, \\
693 \mathrm{~m}, 657 \mathrm{~m}, 632 \mathrm{~m}, 541 \mathrm{~m}, 474 \mathrm{~m}, 459 \mathrm{~m}, 394 \\
\mathrm{~m}, 355 \mathrm{~m}, 326 \mathrm{~m}, 293 \mathrm{w}, 266 \mathrm{~m}, 207 \mathrm{~m}, 173 \mathrm{~m}, 98 \\
\text { m. }\end{array}$ & $\begin{array}{l}3083 \mathrm{~m}, 2823 \mathrm{w}, 1600 \mathrm{~s}, 1521 \\
\mathrm{~m}, 1443 \mathrm{~m}, 1342 \mathrm{~m}, 1329 \mathrm{~m}, \\
1275 \mathrm{~m}, 1228 \mathrm{~m}, 1193 \mathrm{~m}, 1127 \\
\mathrm{~m}, 1095 \mathrm{~m}, 1063 \mathrm{~m}, 958 \mathrm{w}, 829 \\
\mathrm{~m}, 692 \mathrm{w}, 629 \mathrm{w}, 335 \mathrm{w}, 238 \\
\mathrm{w}, 198 \mathrm{w}, 89 \mathrm{~m}, 69 \mathrm{~m}\end{array}$ \\
\hline$\left[\mathrm{HgCl}_{2}(\mathbf{H L})\right] \cdot 2 \mathrm{H}_{2} \mathrm{O}$ & $\begin{array}{l}3382 \mathrm{~m}, 3350 \mathrm{~m}, 3076 \mathrm{~m}, 2903 \mathrm{w}, \mathrm{br}, 1631 \mathrm{~m}, \\
1598 \mathrm{~m}, 1514 \mathrm{~s}, 1478 \mathrm{~m}, 1445 \mathrm{~m}, 1308 \mathrm{~s}, 1252 \mathrm{~s}, \\
1059 \mathrm{~m}, 967 \mathrm{~m}, 906 \mathrm{~m}, 817 \mathrm{~s}, 757 \mathrm{~m}, 736 \mathrm{~m}, 692 \\
\mathrm{~m}, 632 \mathrm{~m}, 539 \mathrm{~m}, 467 \mathrm{~m}, 427 \mathrm{~m}, 359 \mathrm{~m}, 323 \mathrm{~m}, \\
289 \mathrm{~m}, 266 \mathrm{~m}, 239 \mathrm{~m}, 211 \mathrm{~m}, 188 \mathrm{~m}, 147 \mathrm{~m}, 113 \\
\mathrm{~m}, 83 \mathrm{~s} .\end{array}$ & $\begin{array}{l}1632 \mathrm{~m}, 1532 \mathrm{~m}, 1445 \mathrm{~m}, 1378 \\
\mathrm{w}, 1326 \mathrm{~m}, 1310 \mathrm{~m}, 1269 \mathrm{~m}, \\
1245 \mathrm{~m}, 1060 \mathrm{~m}, 965 \mathrm{~m}, 867 \mathrm{w}, \\
840 \mathrm{w}, 707 \mathrm{w}, 634 \mathrm{w}, 474 \mathrm{w}, \\
354 \mathrm{w}, 145 \mathrm{w}, 96 \mathrm{~m}\end{array}$ \\
\hline
\end{tabular}


Table 4. ${ }^{1} \mathrm{H}-\mathrm{NMR}$ spectral data of the ligand and the diamagnetic complexes (the chemical shift values, $\delta_{\mathrm{H}}$, ppm, with coupling constants, $J, \mathrm{~Hz}$, in DMSO-d 6 ).

\begin{tabular}{|l|c|c|c|c|c|c|c|c|}
\hline \multirow{2}{*}{ Compound } & \multicolumn{4}{|c|}{ The benzimidazole protons } & \multicolumn{4}{c|}{ The phenolic protons } \\
\cline { 2 - 10 } & $\mathrm{H} 4$ & $\mathrm{H} 6$ & $\mathrm{H} 7$ & $\mathrm{NH}$ & $\mathrm{H} 3^{\prime}$ & $\mathrm{H} 5^{\prime}$ & $\mathrm{H}^{\prime}$ & $\mathrm{OH}$ \\
\hline $\mathrm{HL}$ & 8.51 & $8.14 \mathrm{dd}$ & $7.78 \mathrm{~d}$ & 13.41 & $8.29 \mathrm{~d}$ & $7.55 \mathrm{dd}$ & $7.04 \mathrm{~d}$ & 12.37 \\
& $\mathrm{~s}, \mathrm{br}$ & $\mathrm{J}=8.9,1.5$ & $\mathrm{~J}=8.8$ & $\mathrm{~s}, \mathrm{br}$ & $\mathrm{J}=2.2$ & $\mathrm{~J}=8.8,2.4$ & $\mathrm{~J}=8.9$ & $\mathrm{~s}, \mathrm{br}$ \\
\hline$\left[\mathrm{Pd}(\mathbf{H L})_{2} \mathrm{Cl}_{2}\right]$ & 8.60 & 8.18 & 7.96 & 12.46 & $8.43 \mathrm{~d}$ & $7.58 \mathrm{dd}$ & $7.12 \mathrm{~d}$ & --- \\
& $\mathrm{s}, \mathrm{br}$ & $\mathrm{d}, \mathrm{br}$ & $\mathrm{s}, \mathrm{br}$ & $\mathrm{s}, \mathrm{br}$ & $\mathrm{J}=2.0$ & $\mathrm{~J}=8.8,2.4$ & $\mathrm{~J}=8.8$ & \\
\hline$[\mathrm{Ag}(\mathbf{H L})(\mathbf{L})] \cdot \mathrm{H}_{2} \mathrm{O}$ & 8.69 & $8.24 \mathrm{~d}$ & $7.55 \mathrm{~d}$ & 10.98 & 7.53 & $6.98 \mathrm{~d}$ & $6.71 \mathrm{~d}$ & 10.20 \\
& $\mathrm{~s}$ & $\mathrm{~J}=8.3$ & $\mathrm{~J}=8.3$ & $\mathrm{~s}, \mathrm{br}$ & $\mathrm{s}$ & $\mathrm{J}=8.8$ & $\mathrm{~J}=8.8$ & $\mathrm{~s}, \mathrm{br}$ \\
\hline$[\mathrm{Cd}(\mathbf{H L})(\mathbf{L}) \mathrm{Cl}] \cdot \mathrm{H}_{2} \mathrm{O}$ & 8.46 & $8.10 \mathrm{dd}$ & $7.76 \mathrm{~d}$ & 13.24 & $8.23 \mathrm{~d}$ & $7.52 \mathrm{dd}$ & $7.01 \mathrm{~d}$ & 12.93 \\
& $\mathrm{~s}$ & $\mathrm{~J}=8.8,2.0$ & $\mathrm{~J}=8.8$ & $\mathrm{~s}, \mathrm{br}$ & $\mathrm{J}=2.4$ & $\mathrm{~J}=8.8,2.4$ & $\mathrm{~J}=8.8$ & $\mathrm{~s}, \mathrm{br}$ \\
\hline$[\mathrm{HgCl}$ \\
& $8.48 \mathrm{H} \mathbf{H})] \cdot 2 \mathrm{H}_{2} \mathrm{O}$ & $8.13 \mathrm{dd}$ & $7.78 \mathrm{~d}$ & - & $8.25 \mathrm{~d}$ & $7.54 \mathrm{dd}$ & $7.02 \mathrm{~d}$ & - \\
& $\mathrm{J}=1.5$ & $\mathrm{~J}=8.8,2.0$ & $\mathrm{~J}=8.8$ & - & $\mathrm{J}=2.4$ & $\mathrm{~J}=8.8,2.4$ & $\mathrm{~J}=8.8$ & -- \\
\hline
\end{tabular}

The proton $\mathrm{H} 4$, neighboring to the nitro group, is observed at $8.51 \mathrm{ppm}$ and it appears at the 8.46-8.69 ppm range at the complexes (Table 4). The $\mathrm{OH}$ proton of $\mathrm{Ag}(\mathrm{I})$ complex shows a different behavior by appearing at higher field according to the other complexes. This may be relevant with a different coordination of the $\mathrm{Ag}(\mathrm{I})$ complex, namely non-chelate structure.

\section{Fluorescence spectroscopy}

Excitation and emission spectra of the compounds were obtained in ethanol at room temperature (excitation wavelength: $354 \mathrm{~nm}$; concentration: $\sim 10^{-4} \mathrm{M}$ ). The emission spectral data are presented in Table 5. The fluorescence spectra of $\mathbf{H L}$ and its $\mathrm{Hg}(\mathrm{II}), \mathrm{Cd}(\mathrm{II}), \mathrm{Ag}(\mathrm{I}), \mathrm{Fe}(\mathrm{III})$ and $\mathrm{Mn}(\mathrm{II})$ complexes are shown in Figure 5.

It was reported that 2-(2'-hydroxyphenyl)benzimidazole (HPBI) and its derivatives can undergo an excited-state intramolecular proton transfer (ESIPT) from the acidic (hydroxyl proton) to the basic site (aromatic nitrogen) when photoexcitation changes their charge density distribution [44-46]. In the ground state, the most stable form of HPBI is usually the enol form. However, in the first excited singlet state, in which the hydroxyl group is much more acidic and the nitrogen much more basic than in the ground state, the most stable structure is usually the keto tautomer. As a result, excitation of the enol form of HPBI tends to be followed by transformation to the keto form in the excited state via ESIPT reaction [46].

The ligand (HL) shows only a strong emission at $460 \mathrm{~nm}$. All the complexes have fluorescence characteristic and considerable changes are observed in the fluorescence spectra of the complexes according to the ligand. The Cd(II) complex exhibited triple fluorescence and $\mathrm{Ni}(\mathrm{II}), \mathrm{Cu}(\mathrm{II}), \mathrm{Ru}(\mathrm{III}), \mathrm{Pd}(\mathrm{II})$ and $\mathrm{Hg}(\mathrm{II})$ complexes showed dual fluorescence while the uncomplexed ligand gave only single fluorescence at $460 \mathrm{~nm}$. A blue shift is observed at $\mathrm{Cu}$ (II) and $\mathrm{Ru}(\mathrm{III})$ complexes whereas the other complexes red-shifted with respect to HL. Intensity of fluorescence generally decreases in the complexes, however in $\mathrm{Co}(\mathrm{II})$ and $\mathrm{Fe}$ (III) complexes it is almost same with the ligand, and increasing is observed at $\mathrm{Mn}$ (II) and $\mathrm{Hg}$ (II) complexes. The keto structure turned into the enol form as a consequence of complexation. And this change will affect the fluorescence characteristics of the complexes with respect to HL significantly. It is observed that all of the compounds have been emitting fluorescence in the visible region. Especially, dual fluorescence of $\mathrm{Ru}(\mathrm{III}), \mathrm{Ni}(\mathrm{II}), \mathrm{Pd}(\mathrm{II}), \mathrm{Cu}(\mathrm{II}), \mathrm{Cd}(\mathrm{II})$ and $\mathrm{Hg}(\mathrm{II})$ complexes is interesting. Thus, these compounds have potential applications as a luminescent material in light-emitting devices. 


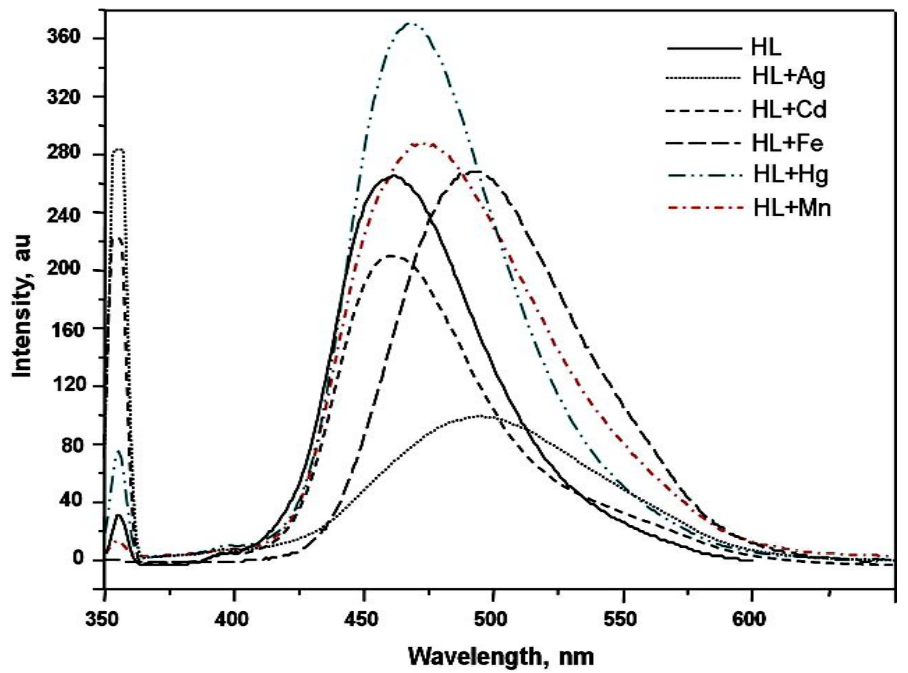

Figure 5. The fluorescence spectra of $\mathbf{H L}$ and $\mathrm{Hg}(\mathrm{II}), \mathrm{Cd}(\mathrm{II}), \mathrm{Ag}(\mathrm{I}), \mathrm{Fe}(\mathrm{III})$ and $\mathrm{Mn}(\mathrm{II})$ complexes in ethanol.

Table 5. UV-Visible and emission maximum wavelengths (nm) of the compounds (in ethanol, $\sim 10^{-4} \mathrm{M}$ ).

\begin{tabular}{|l|l|l|}
\hline Compound & UV-visible data* & Emission maximum* \\
\hline $\mathbf{H L}$ & $230 \mathrm{~m}, 268 \mathrm{~m}, 342 \mathrm{sh}, 349 \mathrm{~m}$ & $460 \mathrm{~s}$ \\
\hline$\left[\mathrm{Mn}(\mathbf{L})_{2}\left(\mathrm{H}_{2} \mathrm{O}\right)\right] \cdot \mathrm{H}_{2} \mathrm{O}$ & $232 \mathrm{~m}, 267 \mathrm{~m}, 350 \mathrm{~m}, \mathrm{br}$ & $469 \mathrm{~s}$ \\
\hline$\left[\mathrm{Fe}(\mathbf{L})_{2}(\mathrm{OH})\left(\mathrm{H}_{2} \mathrm{O}\right)\right] \cdot 2 \mathrm{H}_{2} \mathrm{O}$ & $232 \mathrm{~m}, 284 \mathrm{~m}, 342 \mathrm{~m}, \mathrm{br}, 549 \mathrm{~m}, \mathrm{vbr}$ & $493 \mathrm{~s}$ \\
\hline$\left[\mathrm{Ru}(\mathbf{L})_{2}(\mathrm{DMSO})_{2} \mathrm{Cl}\right] \cdot 4 \mathrm{H}_{2} \mathrm{O}$ & $247 \mathrm{~m}, 291 \mathrm{sh}, 347 \mathrm{~m}, \mathrm{br}, 510 \mathrm{sh}, 581 \mathrm{~m}, \mathrm{br}$ & $394 \mathrm{w}, 457 \mathrm{~m}$ \\
\hline$\left[\mathrm{Co}(\mathbf{H L}) \mathrm{Cl}_{2}\left(\mathrm{H}_{2} \mathrm{O}\right)_{2}\right] \cdot 2 \mathrm{H}_{2} \mathrm{O}$ & $227 \mathrm{~m}, 336 \mathrm{sh}, 264 \mathrm{~m}, 347 \mathrm{~m}, \mathrm{br}, 600 \mathrm{w}, \mathrm{br}, 661 \mathrm{w}, \mathrm{br}$ & $469 \mathrm{~s}$ \\
\hline$\left[\mathrm{Ni}(\mathbf{H L}) \mathrm{Cl}_{2}\left(\mathrm{H}_{2} \mathrm{O}\right)_{2}\right] \cdot 4 \mathrm{H}_{2} \mathrm{O}$ & $232 \mathrm{~m}, 261 \mathrm{sh}, 266 \mathrm{~m}, 338 \mathrm{sh}, 353 \mathrm{~m}$ & $394 \mathrm{w}, 460 \mathrm{~m}$ \\
\hline$\left[\mathrm{Pd}(\mathbf{H L})_{2} \mathrm{Cl}_{2}\right]$ & $249 \mathrm{~m}, 320 \mathrm{~m}, \mathrm{br}, 415 \mathrm{w}, \mathrm{br}$ & $394 \mathrm{w}, 474 \mathrm{w}, \mathrm{br}$ \\
\hline$\left[\mathrm{Cu}(\mathbf{L})_{2}(\mathrm{EtOH})_{2}\right] \cdot \mathrm{H}_{2} \mathrm{O}$ & $237 \mathrm{~m}, 263 \mathrm{~m}, 352 \mathrm{sh}, 399 \mathrm{~m}, \mathrm{br}$, & $394 \mathrm{w}, 452 \mathrm{w}, \mathrm{br}$ \\
\hline$[\mathrm{Ag}(\mathbf{H L})(\mathbf{L})] \cdot \mathrm{H}_{2} \mathrm{O}$ & $230 \mathrm{~m}, 266 \mathrm{~m}, 349 \mathrm{~m}$ & $492 \mathrm{~m}, \mathrm{vbr}$ \\
\hline$[\mathrm{Cd}(\mathbf{H L})(\mathbf{L}) \mathrm{Cl}] \cdot \mathrm{H}_{2} \mathrm{O}$ & $228 \mathrm{~m}, 270 \mathrm{~m}, 351 \mathrm{~m}$ & $397 \mathrm{w}, 459 \mathrm{~m}, \mathrm{vbr}, 547 \mathrm{w}, \mathrm{vbr}$ \\
\hline$\left[\mathrm{HgCl} \mathbf{H L}_{2}(\mathbf{H L})\right] \cdot 2 \mathrm{H}_{2} \mathrm{O}$ & $229,267 \mathrm{~m}, 347 \mathrm{~m}, \mathrm{br}$ & $397,465 \mathrm{~s}$ \\
\hline
\end{tabular}

* vbr: very broad, sh: shoulder, s: strong, m: medium, w: weak, br: broad.

\section{$U V$-visible spectroscopy}

The UV-visible absorption spectra of the compounds were obtained in methanol at room temperature. The UV-visible spectral data are given in Table 5. The UV-visible spectra of the compounds are shown in Figure 6. The electronic spectra of the compounds exhibit intense bands in the 200-400 nm region, which can be assigned to the $n \rightarrow \sigma^{*}, n \rightarrow \pi^{*}$ and $\pi \rightarrow \pi^{*}$ transitions. The bands below $250 \mathrm{~nm}$ are due to the $n \rightarrow \sigma^{*}$ transitions. The compounds exhibit intense intra-ligand absorption bands in the $250-350 \mathrm{~nm}$ region. The $\pi \rightarrow \pi^{*}$ transitions of the aromatic rings are observed in the $250-300 \mathrm{~nm}$ region whereas the $\pi \rightarrow \pi^{*}$ transitions of the $\mathrm{C}=\mathrm{N}$ bond are in between 300 and $350 \mathrm{~nm}$ [47]. The electronic spectra of the complexes are of little help in the present case at the visible region, since the $\mathrm{d} \rightarrow \mathrm{d}$ transitions are masked by the strong charge-transfer transition bands. The very broad bands at 581, 415 and $549 \mathrm{~nm}$ for Ru(III), $\mathrm{Pd}(\mathrm{II})$ and $\mathrm{Fe}(\mathrm{III})$ complexes, respectively, can be attributed to LMCT (ligand to metal charge transfer) transitions. The cobalt complex, $\left[\mathrm{Co}(\mathbf{H L}) \mathrm{Cl}_{2}\left(\mathrm{H}_{2} \mathrm{O}\right)_{2}\right] \cdot 2 \mathrm{H}_{2} \mathrm{O}$, exhibited two weak bands at $600 \mathrm{~nm}\left(16667 \mathrm{~cm}^{-1}\right), 661 \mathrm{~nm}\left(15129 \mathrm{~cm}^{-1}\right)$ which may be assigned to ${ }^{4} \mathrm{~T}_{1 \mathrm{~g}}(\mathrm{~F}) \rightarrow{ }^{4} \mathrm{~T}_{2 \mathrm{~g}}(\mathrm{~F})\left(v_{1}\right)$ 
and ${ }^{4} \mathrm{~T}_{1 \mathrm{~g}}(\mathrm{~F}) \rightarrow{ }^{4} \mathrm{~T}_{1 \mathrm{~g}}(\mathrm{P}) \quad\left(\mathrm{v}_{3}\right)$ transitions, respectively, and these are suggestive of octahedral geometry around the cobalt(II) ions [48, 49].
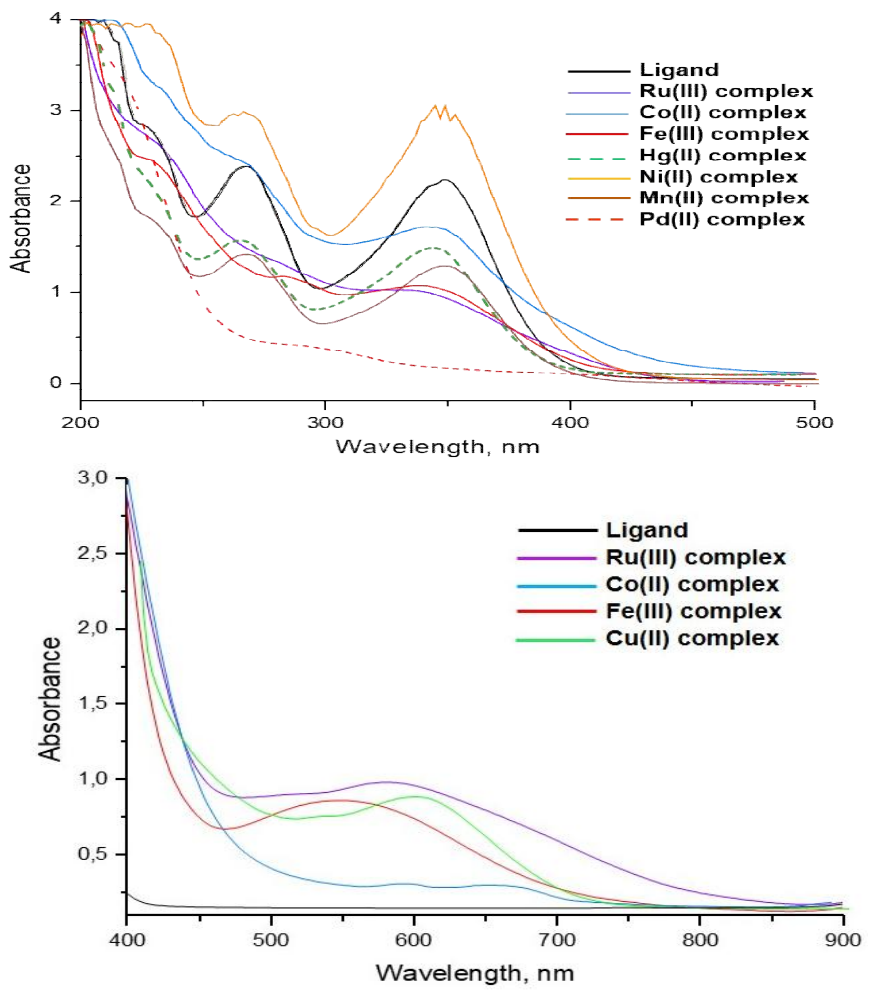

Figure 6. The UV-visible spectra of the ligand and complexes in ethanol.

\section{Antimicrobial activity}

The results concerning in vitro antimicrobial activity of the complexes together with the MIC values are presented in Table 6. Antimicrobial activity of $\mathbf{H L}$ and its $\mathrm{Fe}\left(\mathrm{NO}_{3}\right)_{3}, \mathrm{Cu}\left(\mathrm{NO}_{3}\right)_{2}$ and $\mathrm{Zn}\left(\mathrm{NO}_{3}\right)_{2}$ complexes were reported in previous studies [20, 21]. HL showed considerable activity on S. aureus and S. epidermidis as 2.4 and $19.5 \mu \mathrm{g} / \mathrm{mL}$, respectively. In addition, antibacterial activity of hydrochloride form of $\mathbf{H L}(\mathbf{H L} \cdot \mathbf{H C l})$ toward $S$. epidermidis was 2.4 $\mu \mathrm{g} / \mathrm{mL}$, a remarkable value. It was also reported that the $\mathrm{Zn}(\mathrm{II}), \mathrm{Fe}(\mathrm{III})$ and $\mathrm{Cu}(\mathrm{II})$ complexes was also effective on these two bacteria although weaker compared to the HL ligand [20, 21]. Actually six bacteria and one fungus each with multiple, fresh clinical isolates, have been studied in the antimicrobial activity tests. It is considerable (and expected) result that $\operatorname{Ag}(\mathrm{I})$ and $\mathrm{Hg}$ (II) complexes show strong antimicrobial activity against to all the microorganisms. In addition, the $\operatorname{Ag}(\mathrm{I})$ complex shows prominent activity on $P$. mirabilis and $C$. albicans (MIC values are 39 and $19.5 \mu \mathrm{g} / \mathrm{mL}$, respectively) whereas $\mathrm{AgNO}_{3}$ and the ligand itself do not show any activity towards to these two microorganisms. This can be considered one of the most important results of this study.

It is also observed that the $\mathrm{Pd}(\mathrm{II})$ and $\mathrm{Cd}(\mathrm{II})$ complexes are strongly and selectively effective on $S$. aureus and C. albicans (Table 6). The other complexes - except the Co(II) and $\mathrm{Ru}(\mathrm{III})$ complexes - generally exhibited activity towards $S$. aureus and $S$. epidermidis that they are 
Gram positive bacteria. The Ni(II) complex is more effective on S. epidermidis (MIC: 9.75 $\mu \mathrm{g} / \mathrm{mL}$ ) than the ligand (MIC: $19.5 \mu \mathrm{g} / \mathrm{mL}$ ). The results of our study indicate that the ligand and most of the complexes have the potential to generate novel metabolites, by displaying high affinities towards some of the receptors. The superior antimicrobial activities of the complexes mentioned above against $S$. aureus, $S$. epidermidis and $C$. albicans are considered to be valuable contribution to the researches on metal-based drugs field and encourage working further investigation on these compounds.

Table 6. In vitro antimicrobial activity of the compounds (MIC, $\mu \mathrm{g} / \mathrm{mL})$.

\begin{tabular}{|c|c|c|c|c|c|c|c|}
\hline \multirow{2}{*}{ Compound } & \multicolumn{7}{|c|}{ Microorganisms } \\
\hline & $S a^{\mathrm{a}}$ & $S e^{\mathrm{a}}$ & $E c^{\mathrm{b}}$ & $K p^{\mathrm{b}}$ & $P a^{\mathrm{b}}$ & $P m^{\mathrm{b}}$ & $\mathrm{Ca}$ \\
\hline HL* & 2.4 & 19.5 & $-{ }^{c}$ & - & - & - & - \\
\hline $\mathrm{HL} \cdot \mathrm{HCl}^{*}$ & 2.4 & 2.4 & - & - & - & - & - \\
\hline$\left[\mathrm{Zn}(\mathbf{L})_{2}\right] \cdot 2 \mathrm{H}_{2} \mathrm{O}^{*}$ & 19.5 & 156 & - & - & - & - & - \\
\hline$\left[\mathrm{Fe}(\mathbf{L})_{2}\left(\mathrm{H}_{2} \mathrm{O}\right)_{2}\right]\left(\mathrm{NO}_{3}\right) \cdot 3 \mathrm{H}_{2} \mathrm{O}^{*}$ & 9.8 & 39 & - & - & - & - & - \\
\hline$\left[\mathrm{Cu}(\mathbf{L})_{2}\right] \cdot 2 \mathrm{H}_{2} \mathrm{O}^{*}$ & 19.5 & 39 & - & - & - & - & - \\
\hline$\left[\mathrm{Mn}(\mathbf{L})_{2}\left(\mathrm{H}_{2} \mathrm{O}\right)\right] \cdot \mathrm{H}_{2} \mathrm{O}$ & 4.9 & - & - & - & - & - & - \\
\hline$\left[\mathrm{Fe}(\mathbf{L})_{2}(\mathrm{OH})\left(\mathrm{H}_{2} \mathrm{O}\right)\right] \cdot 2 \mathrm{H}_{2} \mathrm{O}$ & 4.9 & - & - & - & - & - & - \\
\hline$\left[\mathrm{Ru}(\mathrm{L})_{2}(\mathrm{DMSO})_{2} \mathrm{Cl}\right] \cdot 4 \mathrm{H}_{2} \mathrm{O}$ & - & - & - & - & - & - & - \\
\hline$\left[\mathrm{Co}(\mathrm{HL}) \mathrm{Cl}_{2}\left(\mathrm{H}_{2} \mathrm{O}\right)_{2}\right] \cdot 2 \mathrm{H}_{2} \mathrm{O}$ & - & - & - & - & - & - & - \\
\hline$\left[\mathrm{Ni}(\mathbf{H L}) \mathrm{Cl}_{2}\left(\mathrm{H}_{2} \mathrm{O}\right)_{2}\right] \cdot 4 \mathrm{H}_{2} \mathrm{O}$ & 19.5 & - & - & - & - & - & - \\
\hline$\left[\mathrm{Pd}(\mathbf{H L})_{2} \mathrm{Cl}_{2}\right]$ & 4.9 & - & - & - & - & - & 78 \\
\hline$\left[\mathrm{Cu}(\mathbf{L})_{2}(\mathrm{EtOH})_{2}\right] \cdot \mathrm{H}_{2} \mathrm{O}$ & 4.9 & - & - & - & - & - & - \\
\hline$[\mathrm{Ag}(\mathbf{H L})(\mathbf{L})] \cdot \mathrm{H}_{2} \mathrm{O}$ & 4.9 & 39 & 39 & 156 & 39 & 39 & 19.5 \\
\hline$[\mathrm{Cd}(\mathbf{H L})(\mathbf{L}) \mathrm{Cl}] \cdot \mathrm{H}_{2} \mathrm{O}$ & 4.9 & - & - & - & - & - & 39 \\
\hline$\left[\mathrm{HgCl}_{2}(\mathbf{H L})\right] \cdot 2 \mathrm{H}_{2} \mathrm{O}$ & 4.9 & 4.9 & 4.9 & 4.9 & 4.9 & 4.9 & 39 \\
\hline $\mathrm{MnCl}_{2} \cdot 6 \mathrm{H}_{2} \mathrm{O}$ & - & - & - & - & - & - & - \\
\hline $\mathrm{FeCl}_{3} \cdot 6 \mathrm{H}_{2} \mathrm{O}$ & - & - & - & - & - & - & - \\
\hline $\mathrm{CoCl}_{2} \cdot 6 \mathrm{H}_{2} \mathrm{O}$ & - & - & - & - & - & - & - \\
\hline $\mathrm{NiCl}_{2} \cdot 6 \mathrm{H}_{2} \mathrm{O}$ & - & - & - & - & - & - & - \\
\hline $\mathrm{CuCl}_{2} \cdot 2 \mathrm{H}_{2} \mathrm{O}$ & - & - & - & - & - & - & - \\
\hline $\mathrm{Ru}(\mathrm{DMSO})_{4} \mathrm{Cl}_{2}$ & - & - & - & - & - & - & - \\
\hline $\mathrm{PdCl}_{2}$ & - & - & - & - & - & - & - \\
\hline $\mathrm{AgNO}_{3}$ & 9.8 & 4.9 & 4.9 & 4.9 & 4.9 & - & - \\
\hline $\mathrm{CdCl}_{2} \cdot \mathrm{H}_{2} \mathrm{O}$ & - & - & - & - & - & - & - \\
\hline $\mathrm{HgCl}_{2} \cdot \mathrm{H}_{2} \mathrm{O}$ & 0.65 & 0.65 & 1.3 & 0.49 & 10.4 & 1.30 & 2.6 \\
\hline Ciprofloxacin & 0.25 & 0.0625 & 0.0156 & 0.0078 & 1.0 & 0.0156 & - \\
\hline Fluconazole & - & - & - & - & - & - & 1.0 \\
\hline
\end{tabular}

*Taken from literatures 20 and 21. Sa Staphylococcus aureus ATCC 6538; Se Staphylococcus epidermidis ATCC 12228; Ec Escherichia coli ATCC 8739; Kp Klebsiella pneumoniae ATCC 4352; Pa Pseudomonas aeruginosa ATCC 1539 Pm Proteus mirabilis ATCC 14153; Ca Candida albicans ATCC 10231. 'Gram positive; bram negative; ${ }^{\mathrm{c}},-$ : No antimicrobial effect at $5000 \mu \mathrm{g} / \mathrm{mL}$ and lower dilutions.

\section{CONCLUSION}

In the present study, $\mathrm{MnCl}_{2}, \mathrm{FeCl}_{3}, \mathrm{CoCl}_{2}, \mathrm{NiCl}_{2}, \mathrm{CuCl}_{2}, \mathrm{Ru}(\mathrm{DMSO})_{4} \mathrm{Cl}_{2}, \mathrm{PdCl}_{2}, \mathrm{AgNO}_{3}, \mathrm{CdCl}_{2}$ and $\mathrm{HgCl}_{2}$ complexes of $\mathbf{H L}$ were synthesized and characterized by using analytical and spectroscopic techniques such as molar conductivity, magnetic moment, TGA, UV-Vis, FT-IR, FT-Raman, NMR and fluorescence spectroscopy. Their antibacterial and antifungal activities were evaluated by the disk diffusion method against six bacteria and C. albicans as yeast. It was observed that most of the complexes exhibited considerable activity on S. aureus especially. The $\mathrm{Hg}(\mathrm{II})$ and $\mathrm{Ag}(\mathrm{I})$ complexes were found to have superior activity toward all of the microorganisms whereas the $\operatorname{Pd}(\mathrm{II})$ and $\mathrm{Cd}(\mathrm{II})$ complexes showed considerably antimicrobial effect on $S$. aureus and C. albicans selectively. 


\section{ACKNOWLEDGMENTS}

This work was supported by Scientific Research Projects Coordination Unit of Istanbul University. Project numbers: 7011, FMP-2016-23012 and BEK-2017-26875.

\section{REFERENCES}

1. Rizzotto, M. Metal complexes as antimicrobial agents in $A$ search for antibacterial agents, Bobbarala, V. (Ed.), Chapter 5, InTech, Rijeka: Croatia; 2012; 75.

2. Ülküseven, B.; Tavman, A; Ötük, G.; Birteksöz, S. Antimicrobial activity of $\mathrm{Fe}^{\mathrm{III}}, \mathrm{Cu}^{\mathrm{II}}, \mathrm{Ag}^{\mathrm{I}}$, $\mathrm{Zn}^{\mathrm{II}}$ and $\mathrm{Hg}^{\mathrm{II}}$ complexes of 2-(2-hydroxy-5-bromo/nitro-phenyl)-1 $\mathrm{H}$ - and 2-(2-hydroxyphenyl-5-methyl/chloro/nitro-1H-benzimidazoles. Folia Microbiol. 2002, 47, 481-487.

3. Tavman, A.; Agh-Atabay, N.M.; Neshat, A.; Gücin, F.; Dülger, B.; Haciu, D. Structural characterization and antimicrobial activity of 2-(5-H/methyl/chloro- $1 H$-benzimidazol-2-yl)4-bromo/nitro-phenol ligands and their $\mathrm{Fe}\left(\mathrm{NO}_{3}\right)_{3}$ complexes. Transit. Met. Chem. 2006, 31, 194-200.

4. Tavman, A.; Agh-Atabay, N.M.; Güner, S.; Gücin, F.; Dülger, B. Investigation of Raman, FT-IR, EPR spectra and antimicrobial activity of $2-(5-\mathrm{H} / \mathrm{Me} / \mathrm{Cl}-1 H$-benzimidazol-2-yl)phenol ligands and their $\mathrm{Fe}\left(\mathrm{NO}_{3}\right)_{3}$ complexes. Transit. Met. Chem. 2007, 32, 172-179.

5. Seth, G.; Garg, Y.; Mouraya, N.K. Synthesis and characterization of some biological important cobalt(II) chelates of 2-(2'-hydroxyphenyl)benzimidazole. Asian J. Chem. 2002, $14,919-922$.

6. Seth, G.; Garg, Y.; Mouraya, N.K. Studies on some biologically important ternary complexes of nickel(II) with 2-(2'-hydroxyphenyl)benzimidazole and acids. Asian J. Chem. 2003, 15, 546-548.

7. Tavman, A.; Ikiz, S.; Bagcigil, A.F.; Ozgür, Y.N.; Ak, S. Preparation, characterization and antibacterial effect of 2-methoxy-6- $\left(5-\mathrm{H} / \mathrm{Me} / \mathrm{Cl} / \mathrm{NO}_{2}-1 H\right.$-benzimidazol-2-yl)-phenols and some transition metal complexes. J. Serb. Chem. Soc. 2009, 74, 537-548.

8. Tavman, A.; Ikiz, S.; Bagcigil, A.F.; Ozgür, Y.N.; Ak, S. Synthesis, characterization and antibacterial effect of 4-methoxy-2-(5-H/Me/Cl/ $\mathrm{NO}_{2}-1 H$-benzimidazol-2-yl)-phenols and some transition metal complexes. Turk. J. Chem. 2009, 33, 321-331.

9. Tavman, A.; Ikiz, S.; Bagcigil, A.F.; Ozgür, Y.N.; Ak, S. Spectral characterizations and antibacterial effect of 2-methyl-6- $\left(5-\mathrm{H} / \mathrm{Me} / \mathrm{Cl} / \mathrm{NO}_{2}-1 H\right.$-benzimidazol-2-yl)-phenols and some transition metal complexes. Russ. J. Inorg. Chem. 2010, 55, 215-222.

10. Tavman, A.; Cinarli, A.; Gürbüz, D.; Birteksöz, A.S. Synthesis, characterization and antimicrobial activity of $2-\left(5-\mathrm{H} / \mathrm{Me} / \mathrm{F} / \mathrm{Cl} / \mathrm{NO}_{2}-1 H\right.$-benzimidazol-2-yl)-benzene-1,4-diols and some transition metal complexes. J. Iran. Chem. Soc. 2012, 9, 815-825.

11. Tavman, A.; Birteksöz, A.S. Spectral characterization and antimicrobial activity of 4-(5$\mathrm{H} / \mathrm{Me} / \mathrm{Cl} / \mathrm{NO}_{2}-1 H$-benzimidazol-2-yl)-benzene-1,3-diols and some transition metal complexes. Rev. Inorg. Chem. 2009, 29, 255-272.

12. Tavman, A.; Ikiz, S.; Bagcigil, A.F.; Özgür, Y.; Ak, S. Spectral characterizations and antibacterial effect of 2-(5-R-1H-benzimidazol-2-yl)-4-methyl/bromo-phenols and some metal complexes. Bull. Chem. Soc. Ethiop. 2010, 24, 391-400.

13. Tavman, A.; Birteksöz, A.S.; Öksüzömer, F. Spectral and thermal characterization and antimicrobial effect of $3-\left(5-\mathrm{H} / \mathrm{Me} / \mathrm{Cl} / \mathrm{NO}_{2}-1 H\right.$-benzimidazol-2-yl)-benzene-1,2-diols and some transition metal complexes. S. Afr. J. Chem. 2012, 65, 150-158.

14. Sharma, S.; Ramani, J.; Bhalodia, J.; Patel, N.; Thakkar, K.; Patel, R. Synthesis, characterization and antimicrobial activity of some transition metal complexes (Mn, Co, Zn, Ni) with L-proline and kojic acid. Adv. Appl. Sci. Res. 2011, 2, 374-382.

15. Johari, R.; Kumar, G.; Kumar, D.; Singh, S. Synthesis and antibacterial activity of M(II) Schiff base complex. J. Ind. Council Chem. 2009, 26, 23-27. 
16. Mittal, P.; Uma, V. Synthesis, spectroscopic and cytotoxic studies of biologically active new $\mathrm{Co}(\mathrm{II}), \mathrm{Ni}(\mathrm{II}), \mathrm{Cu}(\mathrm{II})$ and $\mathrm{Mn}(\mathrm{II})$ complexes of Schiff base hydrazones. Der Chem. Sinica 2010, 1, 124-137.

17. Kesharwani, R.; Singh, P. Synthesis and biological activity of divalent metal chelates of metronidazole. Asian J. Chem. 2000, 12, 23-26.

18. Kumar, H.; Chaudhary, R.P. Biological studies of a novel azo based heterocyclic Schiff base and its transition metal complexes. Der Chem. Sinica, 2010, 1, 55-61.

19. Habib, S.I.; Baseer, M.A.; Kulkarni, P.A. Synthesis and antimicrobial activity of cobalt(II), nickel(II), and copper(II) complexes of some 2'-hydroxychalcones. Der Chem. Sinica, 2011, $2,27-32$.

20. Tavman, A.; Boz, I.; Birteksöz, A.S. Spectral characterization and antimicrobial activity of 2-(5-chloro/nitro-1H-benzimidazol-2-yl)-4-bromo/nitro-phenols and their zinc(II) complexes. Spectrochim. Acta 2010, A77, 199-206.

21. Tavman, A.; Boz, I.; Birteksöz, A.S.; Cinarli, A. Spectral characterization and antimicrobial activity of $\mathrm{Cu}(\mathrm{II})$ and $\mathrm{Fe}(\mathrm{III})$ complexes of $2-\left(5-\mathrm{Cl} / \mathrm{NO}_{2}-1 \mathrm{H}\right.$-benzimidazol-2-yl)-4-Br/ $\mathrm{NO}_{2}$ phenols. J. Coord. Chem. 2010, 63, 1398-1410.

22. Tavman, A. Synthesis, spectral characterisation of 2-(5-Methyl-1H-benzimidazol-2-yl)-4bromo/nitro-phenols and their complexes with zinc(II) ion, and solvent effect on complexation. Spectrochim. Acta 2006, A63, 343-348.

23. Ridley, H.F.; Spickett, G.W.; Timmis, G.M. A new synthesis of benzimidazoles and aza-analogs. J. Het. Chem. 1965, 2, 453-456.

24. Clinical and Laboratory Standards Institute (CLSI). Methods for dilution antimicrobial susceptibility tests for bacteria that grow aerobically: Approved Standard M7-A5. Wayne, PA: USA; 2006.

25. Clinical and Laboratory Standards Institute (CLSI). Reference method for broth dilution antifungal susceptibility testing of yeasts: Approved Standard M27-A2. 2nd ed., Clinical Laboratory Standards, Wayne, PA: USA; 2002.

26. Clinical and Laboratory Standards Institute. Performance standards for antimicrobial susceptibility testing; 24th informational supplement. M 100-S24:CLSI, Wayne, PA: USA; 2014.

27. Geary, W. The use of conductivity measurements in organic solvents for the characterization of coordination compounds. J. Coord. Chem. Rev. 1971, 7, 81-122.

28. El-Sawaf, A.K.; West, D.X.; El-Saied, F.A.; El-Bahnasawy, R.M. Synthesis, magnetic and spectral studies of iron(III), cobalt(II,III), nickel(II), copper(II) and zinc(II) complexes of 2formylpyridine N(4)-antipyrinylthiosemicarbazone. Transit. Met. Chem. 1998, 23, 565-572.

29. Liao, M.-S.; Watts, J. D.; Huang, M.-J. DFT study of unligated and ligated manganese ${ }^{\mathrm{II}}$ porphyrins and phthalocyanines. Inorg. Chem. 2005, 44, 1941-1949.

30. Basavaraju, B.; Naik, H.S.B.; Prabhakara, M.C. Transition metal complexes of quinolino[3,2-b]benzodiazepine and quinolino[3,2-b]benzoxazepine: Synthesis, characterization, and antimicrobial studies. Bioinorg. Chem. Appl. 2007, 2007, 42587.

31. Maurya, R.C.; Patel, P. Synthesis, magnetic and special studies of some novel metal complexes of $\mathrm{Cu}(\mathrm{II}), \mathrm{Ni}(\mathrm{II}), \mathrm{Co}(\mathrm{II}), \mathrm{Zn}[\mathrm{II}), \mathrm{Nd}(\mathrm{III}), \mathrm{Th}(\mathrm{IV})$, and $\mathrm{UO}_{2}(\mathrm{VI})$ with Schiff bases derived from sulfa drugs, viz., sulfanilamide/sulfamerazine and o-vanillin. Spectrosc. Lett. 1999, 32, 213-236.

32. Earnshaw, E. Introduction to Magnetochemistry, Academic Press: London; 1968; p 35.

33. Das, A.; Peng, S.-M.; Lee, G.-H.; Bhattacharya, S. Synthesis, structure and electrochemical properties of a group of ruthenium(III) complexes of $N$-(aryl)picolinamide. New. J. Chem. 2004, 28, 712-717.

34. Yusuff, K.K.M.; Sreekala, R. Thermal and spectral studies of 1-(2'-hydroxybenzyl)- 2-(2'hydroxyphenyl)benzimidazole complexes of iron(III), cobalt(II), nickel(II) and copper(II). Thermochim. Acta 1991, 179, 313-322. 
35. Soliman, A.A.; Linert, W. Investigations on new transition metal chelates of the 3-methoxysalicylidene-2-aminothiophenol Schiff base. Thermochim. Acta 1999, 338, 67-75.

36. Onwudiwe, D.C.; Ajibade, P.A. Synthesis, characterization and thermal studies of Zn(II), $\mathrm{Cd}(\mathrm{II})$ and $\mathrm{Hg}(\mathrm{II})$ complexes of $\mathrm{N}$-methyl-N-phenyl dithiocarbamate: the single crystal structure of $[(\mathrm{C}(6) \mathrm{H}(5))(\mathrm{CH}(3)) \mathrm{NCS}(2)](4) \mathrm{Hg}(2)$. Int. J. Mol. Sci. 2011, 12, 1964-1978.

37. Tavman, A.; Cinarli, A.; Gürbüz, D.; Birteksöz Tan, A.S.; Oksüzömer, M.A.F.; Tüysüz, M.; Gürkaynak, M.A.; Yalcin, B. Synthesis, spectral characterization and antimicrobial activity of some transition metal complexes of 1,3-bis-(1H-benzimidazol-2-yl)-2-oxapropane. $J$. Chin. Chem. Soc. 2014, 61, 1377-1387.

38. Kanamori, D.; Yamada, Y.; Onoda, A.; Okamura, T.A.; Adachi, S.; Yamamoto, H.; Ueyama. N. Structures and properties of octaethylporphinato(phenolate)iron(III) complexes with $\mathrm{NH} \cdots \mathrm{O}$ hydrogen bonds: modulation of $\mathrm{Fe}-\mathrm{O}$ bond character by the hydrogen bond. Inorg. Chim. Acta 2005, 358, 331-338.

39. Ueyama, N.; Nishikawa, N.; Yamada, Y.; Okamura, T.; Nakamura, A. Structure and properties of tetraphenylporphinate iron(III) complexes with an intramolecular $\mathrm{NH}^{\cdots} \mathrm{S}$ benzenethiolate or $\mathrm{NH}^{\cdots} \mathrm{O}$ phenolate hydrogen bond. Inorg. Chim. Acta 1998, 283, 91-97.

40. Leovac, V.M.; Jovanovic, L.S.; Cesljevic, V.S.; Bjwlica, L.J.; Arion, V.B.; Gerbelu, N.V. Transition metal complexes with the thiosemicarbazide-based ligands-XXIII. Synthesis, physicochemical properties and voltammetric characterization of iron(III) complexes with terdentate and quadridentate thiosemicarbazide derivatives. Polyhedron 1994, 13, 30053014.

41. Nakamoto, K. Infrared and Raman Spectra of Inorganic and Coordination Compounds, Part B, 5th ed., John Wiley and Sons, Inc.: New York; 1997; p. 26.

42. He, H.S.; Huong, J.W.; Ji, L.N. Studies of tailed metalloporphyrins VI. Synthesis, characterization and catalysis of benzimidazole-linked iron(III) porphyrins. Transit. Met. Chem. 1997, 22, 113-116.

43. Sundaraganesan, N.; Meganathan, C.; Anand, B.; Lapouge, C. FT-IR, FT-Raman spectra and ab initio DFT vibrational analysis of $\boldsymbol{p}$-bromophenoxyacetic acid. Spectrochim. Acta 2007, A66, 773-780.

44. Yang, X.-F.; Qi, H.; Wang, L.; Su, Z.; Wang, G. A ratiometric fluorescent probe for fluoride ion employing the excited-state intramolecular proton transfer. Talanta 2009, 80, 92-97.

45. Mosquera, M.; Rodríguez, M.C.R.; Rodriguez-Prieto, F. Competition between protonation and deprotonation in the first excited singlet state of 2-(3'-hydroxy-2'-pyridyl)benzimidazole in acidic solutions. J. Phys. Chem. 1997, A101, 2766-2772.

46. Rodriguez-Prieto, F.; Penedo, J.C.; Mosquera, M. Solvent control of molecular structure and excited-state proton-transfer processes of 1-methyl-2-(2'-hydroxyphenyl)-benzimidazole. J. Chem. Soc. Faraday Trans. 1998, 94, 2775-2782.

47. a) Akkus, Ö.; Uzman, S. Comparison of the ultraviolet-visible spectra of the copper(II) complexes of bidentate Schiff base ligands. Spect. Lett. 2000, 33, 445-455; b) Issa, R.M.; Khedr, A.M.; Rizk, H.F. UV-Vis, IR and ${ }^{1}$ H NMR spectroscopic studies of some Schiff bases derivatives of 4-aminoantipyrine. Spectrochim. Acta 2005, A62, 621-629; c) Habibi, M.H.; Montazerozohori, M.; Lalegani, A.; Harrington, R.W.; Clegg, W. Synthesis, structural and spectroscopic properties of a new Schiff base ligand $\mathbf{N}, \mathbf{N}^{\prime}$-bis(trifluoromethylbenzylidene)ethylenediamine. J. Fluor. Chem. 2006, 127, 769-773.

48. Bagihalli, G.B.; Avaji, P.G.; Patil, S.A.; Badami, P.S. Synthesis, spectral characterization, in vitro antibacterial, antifungal and cytotoxic activities of $\mathrm{Co}(\mathrm{II}), \mathrm{Ni}$ (II) and $\mathrm{Cu}$ (II) complexes with 1,2,4-triazole Schiff bases. Eur. J. Med. Chem. 2008, 43, 2639-2649.

49. Lever, A.B.P. Inorganic Electronic Spectroscopy, 2nd ed, Elsevier: Amsterdam; 1984. 